
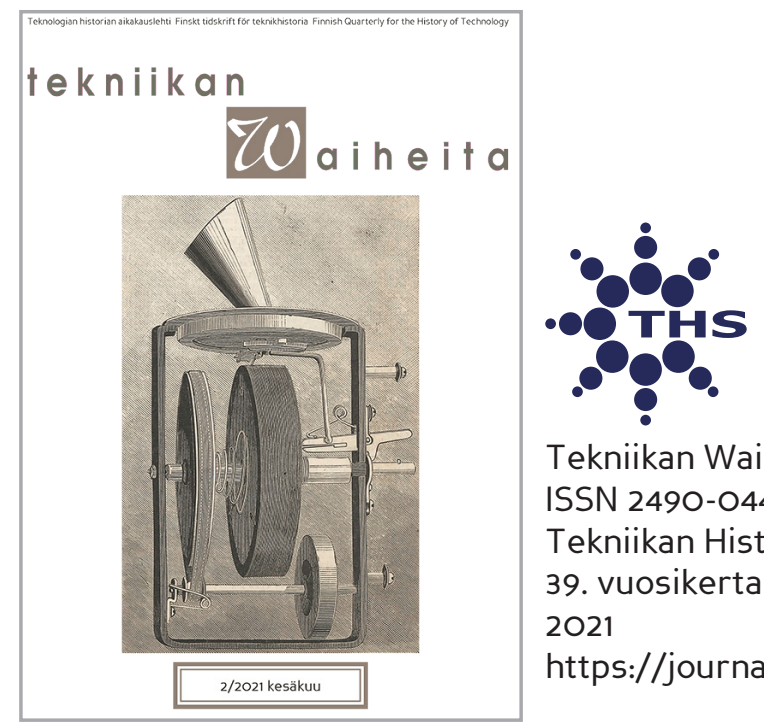

Tekniikan Waiheita

ISSN 2490-0443

Tekniikan Historian Seura ry.

39. vuosikerta: 2

2021

https://journal.fi/tekniikanwaiheita

\title{
$\mathbf{y}$
}

\section{Liuhaseinäisyys pohjalaistaloissa}

Matti Mäkelä

matti.t.makela@helsinki.fi

(iD https://orcid.org/0000-0003-2007-5993

To cite this article: Matti Mäkelä, "Liuhaseinäisyys pohjalaistaloissa" Tekniikan Waiheita 39, no. 2 (2021): 28-53. https://doi.org/10.33355/tw.107951

To link to this article: https://doi.org/10.33355/tw.107951 


\title{
Liuhaseinäisyys pohjalaistaloissa
}

\author{
Matti Mäkelä'
}

Joitakin rakentamisen ratkaisuja pidetään itsestään selvinä. On lähes universaali ilmiö, että rakennuksen seinät tehdään pystysuoriksi. Pohjois-Euroopassa, Pohjanlahden kulttuuripiirissä on kuitenkin alue, missä perinteisten asuinrakennusten seinät levenevät ylöspäin. Rakennus on tällöin liuha. ${ }^{2}$ Muitakin alueellisia nimityksiä on. Vanhoissa kansatieteellisissä kyselyissä ilmiötä ei käsitellä, koska seinien oletettiin olevan pystysuoria. Rakennushistoria ei ole ollut tutkimusalana muodissa, joten hirsirakentamisen tärkeitä periaatteita on tutkittu vähän. ${ }^{3}$ Tämä artikkeli pyrkii osaltaan paikkaamaan tätä puutetta tarkastelemalla liuhaseinäisten rakenteiden toiminnallisuutta.

Artikkeli käsittelee liuhaseinäisen hirsirakentamisen historiaa. Kiinnostus aiheeseen syntyi oman taloni siirtoprojektin yhteydessä, kun selvisi, ettei korkean kaksikerroksisen pohjalaistalon ylöspäin leveneviä seiniä ollut juurikaan tapitettu. Tappien vähälukuisuus ja suoranainen puuttuminen pitkiltä seinäosuuksilta kuusihirsisessä rungossa kiinnitti myös rakentajien huomion.

Kivirakentamisen ja teollisen rakentamisen lainalaisuudet ovat vallinneet Suomessa jo pitkään. Puu ja sen ominaisuudet ovat jääneet marginaaliin sekä tutkimuksessa että käytännön rakentamisessa. Vatupassirakentamisen omaksuneet ovat pitäneet seinien levenemistä kummallisena, vääränä rakentamisena. Viimeistään nyt, ekologisen puurakentamisen noustessa, on aika syventyä ilmiön syihin.

Artikkelin tutkimuskysymyksenä on selvittää, millaiset liuhaseinäisen rakentamistavan ominaisuudet ja funktiot voivat selittää rakennustavan historiallisen käytön Pohjanlahden kulttuuripiirissä ja milloin rakennustapa on ollut käytössä. Liuhaseinäisten asuinrakennusten alueellinen levinneisyys jää jatkotutkimuksen tarkennettavaksi. Oma taloni on ollut keskeisin tutkimuskohteeni, sen parissa olen voinut syventää ajatuksiani ja tutkia asioita tarkemmin. Artikkelin muu aineisto koostuu neljästä liuhaseinäisestä asuinrakennuksesta Etelä-Pohjanmaan sydänalueella. Esimerkkikohteet ovat vanhoja, lähinnä 1700-luvulla rakennettuja asuinrakennuksia ${ }^{4}$, joissa tarkastelun kohteena oleva ominaispiirre on ollut selvästi havaittavissa. Kaikissa tarkastelun kohteena olleissa taloissa tupa on rakennuksen päädyssä. Valinta kohdistui joukkoon vanhimpia säilyneitä pohjalaistaloja, sillä ilmiön syiden selvittämiseksi on tarkoituksenmukaista tutkia kohteita, jotka ovat lähimpänä ilmiön synty-

\footnotetext{
${ }^{1}$ Kirjoittaja on filosofian maisteri, joka valmistelee väitöskirjaa Helsingin yliopiston kansatieteen oppiaineessa.

${ }^{2}$ Toivo Vuorela ottaa rakennustavan nimityksinä esiin termit liuha ja illo. (Vuorela 1949, 56.) Liuha tarkoittaa vinoa tai viistoa. Illo on myös ylöspäin levenevä rakennus, astia tai esine; myös työkalu, jonka terä on liian suuressa kulmassa varteen nähden. (Kulonen toim. 1995, 68, 84; Itkonen toim. 1992, 224.) Trattinen on KeskiPohjanmaalla, Perhonjokilaaksossa piirteestä käytetty nimitys, mikä Etelä-Pohjanmaan Järviseudulla on muodossa rattinen. Tratti on suppilo eli merkitys on suppilomainen. (Kulonen toim. 2000, 84.)

${ }^{3}$ Ks. Andersson 2016, 21.

${ }^{4}$ Ks. LIITE 1.
} 
aikaa. Ilmiön muutoksen tutkiminen vaatisi huomattavasti monipuolisemman ja laajemman otannan eli taloja myös 1800-luvun eri vuosikymmeniltä.

Talot ovat aina yksilöitä. Erilaiset esteet ja turvallisuussyyt ovat vaikuttaneet siihen, kuinka paljon olen voinut ottaa mittoja esimerkkirakennuksesta tutkimusta varten. Olen mitannut talon leveyden alhaalta yleensä talon ulkopuolelta sekä tasakerrasta vintiltä.

Rakentamista koskevassa kirjallisuudessa ja arkistoaineistossa hirsirakennuksen liuhaseinäisyyttä on käsitelty hämmästyttävän vähän. Tämän artikkelin keskeisenä kirjallisena aineistona on Suomalaisen Kirjallisuuden Seuran (SKS) hirsirakentamista koskevat käsikirjoitukset, Svenska Litteratursällskapetin hirsirakentamista koskevat keruuaineistot ja Museoviraston hirsirakentamiseen liittyvät kyselyt, jotka ovat olleet erityisesti kansatieteellisen Etelä-Pohjanmaan osalta tarkasteltavana. Arkistoaineiston merkitys pohjalaistalon historian ja kerrostuneisuuden ymmärtämisessä on suuri, koska talossa kaikki vaikuttaa kaikkeen. Yksityiskohdissa voi avautua koko talon rakenne ja sen takana olevat periaatteet; kaikki, mitä rakentamisessa pidettiin tärkeänä.

Suomen, Ruotsin ja Norjan perinteisessä hirsirakentamisessa on runsaasti yhtäläisyyksiä, mutta myös omaleimaisia eroja, joiden perusteella alueet voi tunnistaa. Liuhaseinäisyys on yksi pohjalaistalojen huomiota herättävimmistä piirteistä. Se on ollut leimallinen Pohjanlahden pohjoiselle rannikkoalueelle ja sen kulttuuripiirille. Rakennustapa painottuu historiallisen Pohjanmaan maakunnan alueelle, mutta sitä on esiintynyt myös Norjassa ja Ruotsissa.

\section{Liuhaseinäinen pohjalaistalo}

Pohjanmaalla kävijän huomio kiinnittyy vanhojen asuinrakennusten runkojen levenemiseen räystäitä kohti. Tämä liuhaseinäisyys on tyypillistä vanhemmille pohjalaistaloille. ${ }^{5}$ Rakentamistapa muuttui Pohjanmaalla 1850-1870, jonka jälkeen rakennetut pohjalaistalot ovat suoraseinäisiä. ${ }^{6}$

Pohjanmaan historiallinen varallisuus perustui tervakauppaan ja laivanrakennukseen. Pohjanmaa oli Ruotsin valtakunnan keskeinen laivanrakennusalue maakunnan kirvesmiesten ollessa laivaveistämöiden sesonkityövoimaa. ${ }^{7}$ Pohjalaistaloja yhdistävä piirre on korkea runko. Pohjanmaan rannikkokaupunkeihin rakennettiin kaksikerroksisia taloja etenkin pikkuvihan jälkeen ja niitä alkoi ilmestyä Pohjanmaan maaseudulle jo 1700-luvun jälkipuolella. ${ }^{8}$ Liuhaseinäisyyttä esiintyy sekä puolitoistakerroksisissa että kaksikerroksisissa pohjalaistaloissa.

\footnotetext{
${ }^{5}$ Bonns 1983, 173. Suoraseinäisiä asuinrakennuksia on Pohjanmaalla myös vanhemmissa asuinrakennuksissa. Ne ovat usein säätyläisten rakennuttamia, kuten Närpiön Ivars, mikä on alun perin ollut mansardikattoinen talo. (Hämäläinen 1929, 14.)

${ }^{6}$ Suoraseinäisissä taloissa on yleensä kattotuolirakenne, kuten Alavuden Mäki-Haanpäässä rv. 1861 tai Lapuan Antilassa rv. 1876. (Potra-kenttätyövihko, 27, 76-77 MMK; Vuorela 1949, 59, 64.) 1880- ja 1890-lukujen pohjalaistalot ovat kauttaaltaan suoraseinäisiä. (Ks. Jaakkola 2015, passim.)

${ }^{7}$ Ks. Toivanen 1982; Toivanen 1983.

${ }^{8}$ Nikander 1944, 112, 114; Luukko 1979, 85, 87; Vuorela 1949, 58-59. Rakennuksistaan tunnetun Kuortaneen tiettävästi ensimmäinen kaksikerroksinen asuinrakennus tehtiin Kuortaneen vanhan kirkon hirsistä, pitäjän ensimmäisen kruununvoudin Erik Björkin rakennuttamana. (Klemetti (1932) 1987, 180-181; 188-190; Tiedonanto Jouko Ämmälä 1.10.2003. Kenttäpäiväkirja IV, 35, MMK.) Ei ole poissuljettua, että uuden edustavan rakennuksen laittoi alulle Kuortaneen kirkkotyömaan mestarina toiminut Antti Hakola. Todennäköisesti rakentajina toimivat Kuortaneen 1777 valmistuneen kirkon tehneet kirvesmiehet.
} 
Liuhaseinäisessä hirsirakennuksessa seinähirsien pituudet kasvavat ylöspäin mentäessä. Vanhoissa liuhaseinäisissä taloissa hirsiä toisiinsa sitovia tappeja käytettiin lähinnä aukkojen ja päätykolmioiden yhteydessä. Tappeja alettiin käyttää enemmän 1800-luvulla, kun reikien tekemisessä käytettävät porat kehittyivät. ${ }^{9}$ Restaurointimestari Erkki Hiipakan mukaan tappeja käytettiin enemmän hirsien pitkittäisen kuin poikittaisen liikkeen estämiseksi. Vanhimmissa taloissa tappeja ei käytetty juuri ollenkaan, esimerkiksi päätykolmioissa hirret yhdistettiin seinän sisäpuolelta naralla. ${ }^{10}$

Kaikissa lämpimissä asuinrakennuksissa seinähirret on täytynyt varata. Alemman hirren selän muoto on piirretty hirsivaralla ylempään hirteen, jonka alapuoleen on veistetty alemman hirren selkään sopinut kouru. Varatussa hirsisalvoksessa puu tulee tiiviisti puuta vasten. Tämä kuuluu sekä Suomen, Ruotsin että Norjan hirsirakentamiseen. Mitä leveämpi on varaus, sitä enemmän rakennus painuu ja sitä tiiviimpi ja lämpimämpi rakennuksesta tulee edellyttäen, että varaus tilkitään kunnolla. Leveä varaus on tehnyt seinästä myös rakenteellisesti vakaan. ${ }^{11}$

Perinteiset hirsirakennukset on yleensä veistetty melko tuoreesta puusta, sillä hirren työstäminen kirveellä on silloin paljon helpompaa. ${ }^{12}$ Kirveelle ominaisia viistoja pintoja löytyy vanhoista nurkkasalvoksista, joista esimerkiksi viistokaulainen sulkanurkka tiivistyi laskeutuessaan jatkuvasti. Vasta sahan käytön yleistyessä ryhdyttiin käyttämään enemmän myös vanhoja hirsiä, sillä sahan avulla suorakulmaisten salvosten teko kovaan puuhun oli helpompaa. Työstettävyyden lisäksi lamasalvostekniikan pohjoisilla alueilla tuoreen puun kutistuminen oli rungon painumisessa tärkeä elementti. Tuore seinä saattoi tiivistyessään menettää korkeudestaan tuuman seinämetriä kohti. ${ }^{13}$ Runsaasti sydänpuuta sisältävät nurkat eivät painuneet niin paljon kuin seinän keskiosat. ${ }^{14}$ Vanhemmat talot tehtiin joko rakennuspaikalla tai metsässä, mistä rakennuspuut kaadettiin. Jälkimmäisessä tapauksessa runkoon ei tehty ikkuna- ja oviaukkoja, eikä sitä myöskään tapitettu. Pohjanmaan talonpoikaista rakentamista tutkineen Bertil Bonnsin mukaan jotkut rungot ovat saattaneet kuivua ilman kattoa kauankin, minkä näkee rungon piiluamattomista osista. Kuivumisajan pituus on kuitenkin vaihdellut tarpeen mukaan myös vanhemmissa taloissa. ${ }^{15}$

\footnotetext{
${ }^{9}$ Bonns 1983, 176.

${ }^{10}$ Tiedonanto Erkki Hiipakka 7.9.2013. Potra-kenttätyövihko, 9, MMK; Kenttätyöpäiväkirja, 21, 141, MMK. "Entisaikaan käytettiin salavaarnojen sijasta päätypölkkyjä paikoillaan pitämässä pienat, narat, jotka oli sisäpuolelle päätyyn uurrettu." (Paulaharju 1908, 153, Rakennuksista. Etelä-Pohjanmaa. Käsikirjoitus. SKS KRA E10.)

${ }^{11}$ Andersson 2016, 39, 41. Lämmittämättömässä rakennuksessa, esimerkiksi aitassa varausta ei ole tarvinnut tehdä leveäksi.

12 Bonns 1983, 172.

${ }^{13}$ Sjömarin informanttien mukaan painuminen on kevään kuivuneella hirrellä 1,7-2,7 cm seinän korkeusmetrille. (Sjömar 1988, 65.)

${ }^{14}$ Ervi 1946, 258.

15 Bonns 1983, 178; Haaramo \& Hautala, 6-7, Rakennustavasta Isojoella. Käsikirjoitus. KA. Lapista Pohjanmaan rannikkoa Vaasaan matkannut Cambridgen mineralogian professori Edvard Daniel Clarke kirjoittaa matkapäiväkirjassaan 1799 seuraavaa: "Kaikkialla Pohjanlahden alueella noudatetaan samaa tapaa kuin Venäjälläkin. Sen mukaan talot rakennetaan metsässä, minkä jälkeen ne hajoitetaan osiin ja kuljetetaan sinne, missä niitä on määrä käyttää asuntona." (Clarke (1819) 2000, 64.) Ruotsista Taalainmaalta on tieto, että hirret tavallisesti haettiin seuraavan talven rekikeleillä eli runko ehti painua metsässä vuoden verran. Tässä yhteydessä käytetään termiä råtimringsteknik, jota käytettiin Pohjois-Ruotsin hirsirakentamisessa pitkälle 1800-luvulle. Arnstbergin mukaan Etelä- ja Keski-Ruotsissa alettiin käyttää kuivuneita hirsiä ja suoria salvoksia jo 1600 -luvulla. (Arnstberg 1976, 41-42.)
} 
Liuhaseinäiset pohjalaistalot kuuluvat aikaan, jolloin pohjalaistalon runko tehtiin nurkkakivien varaan. Tällöin rungon paino ei jakautunut tasaisesti, vaan kohdistui pistekuormana nurkkakiviin seinän nurkkaketjun kautta. Nurkkasalvosten piti olla erityisen hyvin tehtyjä, sillä ne pitivät rakenteen koossa. Hirsirakennuksen seinän heikoin kohta on nurkista piirrettyjen viivojen leikkauskohdassa, kaukana nurkkaketjuista. ${ }^{16}$

Liuhaseinäiset talot olivat alun perin vuoraamattomia. Talojen ulkovuoraus alkoi Pohjanmaalla yleistyä vasta 1800 -luvun loppukymmenillä sahatavaran saatavuuden parantuessa. Aikaa myöten myös talojen ikkunat suurenivat ja niiden määrä kasvoi 1800-luvun lopussa. Aukkojen lisääntymisen myötä seinän tukemiseen ryhdyttiin käyttämään pystypiiruja eli följäreitä. ${ }^{17}$

Liuhaseinäisissä rakennuksissa on vuoliaiskatto. Vuoliaiskatto on perinteinen, hirsirakentamiseen kuulunut kattotyyppi, mikä edellyttää rakennuksen pääty- ja väliseinien tekemistä hirrestä, aina rakennuksen harjalle asti. Näiden hirsisten kolmioiden varaan on asetettu pyöreät puunrungot, vuoliaiset, jotka ulottuvat jonkin verran pääty- ja väliseinien ulkopuolelle. Vanhimmissa rakennuksissa vuoliaiset asetettiin hirsikolmion jokaisen hirren päälle, tällöin kolmioissa ei käytetty tappeja. Pohjalaistaloissa oli yleensä harjahirren lisäksi 2-3 vuoliaisparia, talon leveydestä riippuen. Mikäli vuoliaisia on vähän, niiden päälle tulevat ruoteet vievät osan katon painosta kohdistaen sitä myös sivuseinille. Pääasiassa vuoliaiskaton paino on pääty- ja väliseinien varassa. Vuoliaiskaton katsotaan soveltuneen erityisen hyvin taloon, missä välipohjapalkistolla pystyttiin kuormittamaan myös sivuseiniä. Kattokulma liuhaseinäisissä rakennuksissa on ollut hyvin loiva. Vuoliaiskatto on ollut perinteisesti malkakatto, myöhemmin myös lautakatto. ${ }^{18}$

Asuinkäytön päätyttyä vanhoja liuhaseinäisiä taloja on tyypillisesti käytetty navettoina ja niittylatoina, minkä seurauksena ne ovat aikojen saatossa tuhoutuneet. Kuitenkin jotkut vanhoista asuinrakennuksista palvelevat edelleen laajennetun pohjalaistalon osana.

Svenska Litteratur Sällskapetin 1915 keräämässä hirsirakentamista käsittelevässä aineistossa närpiöläinen tiedonantaja mainitsee ennen käytetyn ulospäin kallellaan olevia pitkiänurkkia, joiden hän sanoi levinneen kuusi tuumaa. Tämä vastaa seinähirren tavallista paksuutta. ${ }^{19}$

Jalasjärveltä perinteenkerääjä Samuli Paulaharju kirjoittaa 1908 seuraavaa:

\section{Luodilauta oli samalla nurkanpään mittaus. Ennen tehtiin seinät "levittään", nyt tehdään "luodis". Levittäen = Seinät kallistui hiukan ulospäin. Nïn paljon levis, jotta puoli tuu- maa sylellen. Luodilaudalla määrättiin, kuinka paljon se kallisti. ${ }^{20}$}

Paulaharjun mitta seinän levenemiselle on erittäin vähäinen ja kertoo todennäköisesti liuhaseinäisen rakentamisen loppuvaiheista 1800-luvun jälkipuolella. Luotilaudan leveys oli yleensä sama kuin seinän paksuus. Kuten Paulaharju toteaa, luotilaudan leveys oli myös nurkanpään mitta. Bertil Bonnsin mukaan luotilauta oli tavallisesti noin kyynärän mittainen ja

\footnotetext{
${ }^{16}$ Ks. Sjömar 1988, 73. Yhtenäinen, lohkokivistä tehty kivijalka kuuluu 1800-luvun jälkipuolen suoraseinäisiin pohjalaistaloihin.

17 SLS 257, 185; Bonns 1983, 203-204; Ks. Puurunen 1995, 13-14.

${ }^{18}$ Sjömar 1988, 66, 152-157; Bonns 1983, 181-184. Kattotuolien varassa olevan katon paino kohdistuu rakennuksen sivuseinille.

${ }^{19}$ SLS 257, 161.

${ }^{20}$ Paulaharju 1908, 205-206. Rakennuksista. Etelä-Pohjanmaa. Käsikirjoitus. SKS KRA E1O.
} 
liuhaseinäiset talot levenivät entisaikaan kyynärän matkalle tuuman verran. ${ }^{21}$ Keski-Pohjanmaalta Vetelistä on tieto, jonka mukaan seinän piti levetä ohranjyvän verran hirsivarville. ${ }^{22}$ Jos hirsirakennuksen tavanomainen hirrenkorkeus seinässä on noin $20 \mathrm{~cm}$ hirsikerralta, niin kyynärän eli noin $60 \mathrm{~cm}$ matkalle hirsikertoja mahtuu kolme. Kun ohranjyvä pituusmittana on kolmannestuuma, niin tuuma kyynärälle ja ohranjyvä hirsikerralle ovat mittoina yhdenmukaiset. "Tuuma kyynärälle" -mitta lienee syntynyt siinä vaiheessa, kun kuusituumaisen seinän korkeus on ollut kuusi kyynärää eli 3,60 m. Seinän korkeuden yhä kasvaessa mittaa on pienennetty, jotta seinän vinous ei ylittäisi alkuperäistä seinän paksuutta.

\section{Liuhaseinäisyyden historia}

Lamasalvostekniikka on ollut laajasti levinnyt pohjoisen havumetsävyöhykkeen rakennustapa, mutta asuinrakennusten liuhaseinäisyys painottuu Pohjanmaalle. Ladoissa ja aitoissa piirrettä esiintyy laajemmalla alueella Pohjanlahden kulttuuripiirissä. ${ }^{23}$ Liuhaseinäisyyden juuria on etsittävä vanhoista ja korkeista hirsirakennuksista. Ensimmäisiä piirroksia liuhaseinäisyyteen viittaavasta rakentamistavasta on Reginald Outhierin piirros vuodelta 1736:

Torniosta jokea ylöspäin mentäessä on jokaisella talonpojalla Cotta-niminen lisärakennus. Se on yläosastaan leveämpi kuin alhaalta ja itse taloa korkeampi ja sen katolla on tuuliviiri pitkän seipään nenässä. ${ }^{24}$

Piirros dokumentoi Pellon Korteniemestä Tornionjoen varrelta talonpoikaistalon pihapiiristä tornimaisen kotarakennuksen. Se levenee silmin nähden ylöspäin kohoten selvästi muita rakennuksia korkeammalle. ${ }^{25}$ Ruotsin Lapin Arvidsjaurista tunnetaan neliömäinen harjakota, jonka kattoriukujen pohjana on neljästä hirsikerrasta muodostuva seinäkehikko, jonka jokainen

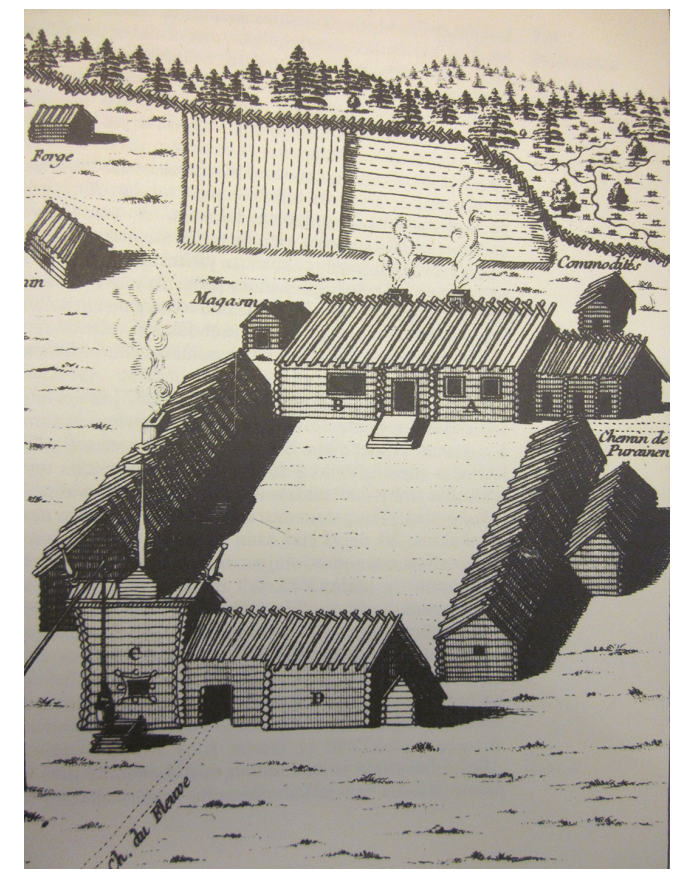

Kuva 1. Pellon Korteniemi, osa piirroksesta vuodelta 1736. Etualalla ylöspäin levenevä, tornimainen kotarakennus. Kirjasta Outhier (1744) 2011: Matka Pohjan perille 1736-1737, s. 116.

\footnotetext{
${ }^{21}$ Bonns 1983, 173-174.

22 Tiedonanto Lauri Tunkkari 20.6.1999. Kenttäpäiväkirja II, 26, MMK. Tämä on mielenkiintoinen tieto, sillä ohranjyvä on ikivanha, todennäköisesti germaanista perua oleva anglosaksinen pituusmitta. Ohranjyvä oli kolmannestuuma eli hieman yli 8 mm. (Keskiaikaiset mitat. http://www.katajala.net/keskiaika/elama/mitat. htm).

23 Sirelius 1921, 252.

${ }^{24}$ Outhier (1744) 2011, 106-107.

${ }^{25}$ Kuva 1. Outhier (1744) 2011, 116.
} 


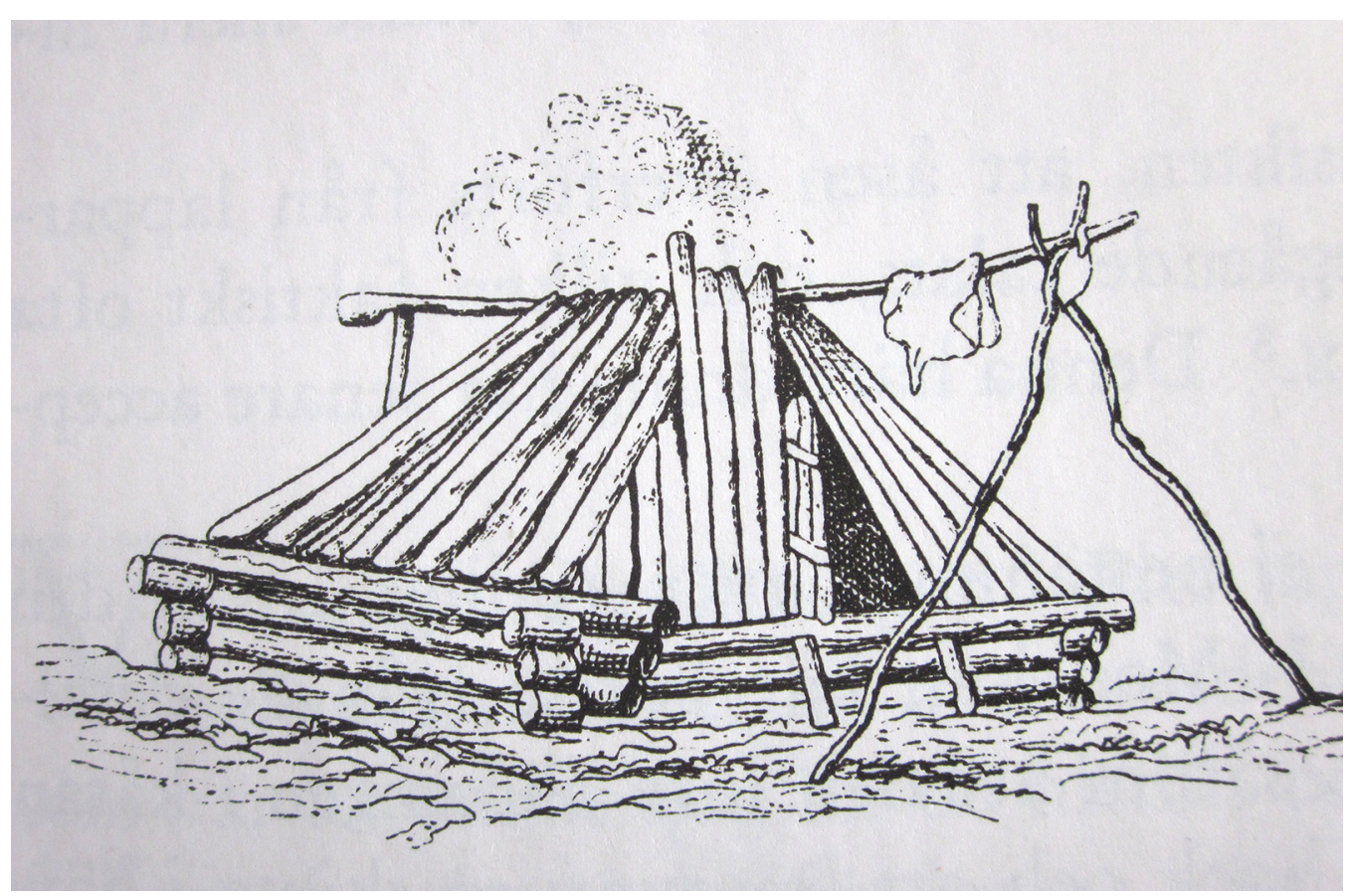

Kuva 2. Kodan liuha alusta, Arvidsjaur. Mandelgrenin Atlaksen mukaan. Kirjasta Erixon (1947) 1982: Svensk Byggnadskultur, s. 62.

hirsi pitenee ylöspäin. Ylöspäin laajeneva alusta on hyvänä pohjana pitkille kattopuille. Tämän tyyppistä kotaa pidetään välivaiheena siirryttäessä pyramidikattoisesta kodasta satulakattoiseen hirsirakennukseen. ${ }^{26}$

Akateemikko Kustaa Vilkuna on esittänyt teorian, että kodan jalustarakenteen kasvaessa hirsi hirreltä on muodostunut hirsiseinä, jolloin entisistä pistekodan seinistä on muodostunut katto. Näin oltaisiin kodasta päädytty hirsirakennukseen. ${ }^{27}$

Yksi vanhimmista säilyneistä liuhaseinäisistä rakennuksista sijaitsee Torniossa. Tornion tapuli rakennettiin 1686-88 liminkalaisen mestarin, Matti Härmän johdolla. Professori Lars Petterssonin mukaan 1663 rakennettu ja 1733 uudella korvattu Limingan vanha tapuli on todennäköisesti ollut Tornion tapulin esikuvana. Tornion tapuli on kahdeksankulmainen rakennus, jonka keskellä on läpikäytävä. Ulkoseinien ja läpikäytävän väliin jäävät hirsiarkut, jotka on osittain täytetty kivillä. Ensimmäinen kerros ei ole korkea, mutta ulkoseinät levenevät hyvin voimakkaasti ulospäin. ${ }^{28}$

Pohjanmaan kirkoista Lars Pettersson mainitsee Koivulahden 1690-luvun alussa rakennetun kirkon seinät voimakkaasti ylöspäin leveneviksi. Koivulahden kirkko on ollut alun perin kahdeksankulmainen ja muutettu 1794-95 ristikirkoksi. Laajennuksen yhteydessä myös

\footnotetext{
${ }^{26}$ Kuva 2. Erixon (1947) 1982, 62.

27 Vilkuna 1946, 374-375.

${ }^{28}$ Pettersson 1985, 157-160.
} 
uudet ristisakarat veistettiin ylöspäin leveneviksi. Vaikka myöhemmissä korjauksissa seiniä on pyritty oikaisemaan laudoituksella, liuhaseinäisyys on edelleen silmämääräisesti havaittavissa lukuisissa pohjalaisten rakentajien toteuttamissa puukirkoissa ja tapuleissa. ${ }^{29}$

Norjan, Ruotsin ja Suomen puukirkkotutkijat ovat kiinnittäneet huomiota pohjalaisten rakentajien innovaatioihin, esimerkiksi pohjalaisiin tukipilarikirkkoihin. Liuhaseinäisyyttä ei ole näissä tutkimuksissa kuitenkaan mainittu. ${ }^{30}$ Tukipilarikirkkojen rakenteita tutkineen Antti Haikalan mukaan tukipilarien pääasiallinen tarkoitus oli rakenneosien yhteen liittäminen eli kirkkotilan jatkaminen ja kuormien siirtäminen perustuksille, ei niinkään kirkon jäykistäminen. Tukipilarikirkot ovat kattotuolillisia ja varsin jyrkkäkattoisia rakennuksia pienikokoisia Sodankylää ja Jukkasjärveä lukuun ottamatta. ${ }^{31}$ Rakennustyyppeinä tukipilarikirkot ja liuhaseinäiset talot ovat varsin erilaisia. Tukipilarikirkoissa suurimman tuulikuorman ottaa vastaan katto ja liuhaseinäisissä taloissa seinä.

Liuhaseinäisiä taloja löytyy pohjalaisten rakentajien vaikutuksesta myös muualta Suomesta. Ruotsissa piirre on huomattavasti harvinaisempi ja kansatieteilijä Karl-Olov Arnstbergin mukaan rakennustapaa näyttää esiintyvän lähinnä Norlannin suomenkielisissä pohjoisosissa. Aittojen tapaan kaartuvaa seinän yläosaa tai liuhaa seinää on esiintynyt kyseisen seudun ennen 1700-luvun loppua tehdyissä asuinrakennuksissa. Taalainmaan vanhakantaisessa rakennuskannassa on ilmeisesti joitakin rakennustapaa edustavia poikkeustapauksia. ${ }^{32}$ Norjassa liuhaseinäisiä taloja vaikuttaa olleen enemmän kuin Ruotsissa. Norjan puuarkkitehtuurin asiantuntijan Halvor Vreimin mukaan kaksikerroksisia, liuhaseinäisiä asuinrakennuksia on tehty Østlandetin ja Trøndelagin alueilla vuoden 1770 tienoilla. Tyypin norjalaisissa kaksikerroksisissa taloissa leveneminen kivijalasta tasakertaan on ollut noin $20 \mathrm{~cm} .{ }^{33}$

Suomessa on inventointiresurssien puuttumisen takia saatavissa hyvin vähän tietoa 1600-luvun rakennuskannasta. Tuohon aikaan yleistyivät uloslämpiävät asuinrakennukset ja hirsien pelkkaaminen. ${ }^{34}$ Pohjanmaalla tuon vuosisadan säilyneet rakennukset ovat lähinnä riihï ja aittoja. Liuhaseinäisen rakentamisen alkuhistorian kannalta mielenkiintoinen on kuva vuoden 1621-riihirakennuksesta Ähtävän Kirkonmäeltä. ${ }^{35}$ Siinä rakennuksen seinät ovat suorat, mutta pääty- ja väliseinien hirrenpäät pitenevät ylöspäin mentäessä. Tämän perusteella rakennustavan syntyminen voidaan ajoittaa 1600 -luvulle.

\footnotetext{
${ }^{29}$ Ks. Pettersson 1985, 174-175, 382-391, 269, 454.

${ }^{30}$ Ks. Sjöström, Knapas \& Storsletten 2000. Pohjalainen tukipilarikirkko syntyi 1400 -luvun lopulla. (Ks. Pettersson 1987)

${ }^{31}$ Haikala 2010, 75, 27. Tukipilarien ja liuhaseinäisyyden otaksuu helposti esiintyvän eri rakennuksissa, mutta kuvien perusteella voi todeta Ruotsin Lapissa sijaitsevan Jukkasjärven tukipilarikirkon olevan myös liuhaseinäinen. (Ks. Beskow 1952, 48-50.)

${ }^{32}$ Arnstberg 1976, 81-83.

${ }^{33}$ Vreim 1937, 2. Ruotsalainen tutkija Peter Sjömar on mitannut tyypin norjalaisia taloja ja kertoo seinän levenevän noin $5 \mathrm{~cm}$ kerrosta kohti, mikä vastaa Vreimin mittaa. (Sjömar 1988, 78.) Norjalaisessa taiteessa näkyy myös merkkejä liuhaseinäisyydestä. Esimerkiksi Harriet Backerin talonpoikaisinteriööri Lekseoverhöring $i$ Eggedal, vuodelta 1888, tuo esiin vanhan talonpoikaistuvan liuhaseinäisyyden.

${ }^{34}$ Korhonen 2011, 29.

${ }^{35}$ SLS 373, 40. Kuva on vuodelta 1924.
} 


\section{Liuhaseinäisyyden funktiot}

Etelä-Pohjanmaalla kuulee usein sanottavan, että liuhaseinäinen rakennus on tehty "komian tähären”, näyttävyyden takia. Esteettisiä syitä ei voi vähätellä, mutta yleensä niiden taustalta löytyy myös käytännön syitä, jotka ajan kuluessa ovat unohtuneet.

Liuhaseinäisyys on leimallisesti kuulunut Pohjanmaan alueelliseen rakennustapaan. Sama estetiikka löytyy myös vanhemmista norjalaisista hirsitaloista. Halvor Vreim on nostanut esiin Norjan vanhassa rakennuskannassa vaikuttaneen käsitteen soliditetskravet. Nykymaailmassa suora käännös on taloustermi: vakavaraisuusvaatimus. Tällä on tarkoitettu perinteisessä rakentamisessa vallinnutta yleistä periaatetta, jonka mukaan rakennus on pyritty tekemään kestäväksi, näyttäväksi ja ylläpidettäväksi. Rakennuksen linjat on tehty niin, että ne työskentelevät luhistumista vastaan. Näistä nykyäänkin tunnetaan rakennuksen katonharjan tekeminen niin, että harja on keskeltä jonkin verran päätyjä ylempänä. Mikäli katon harja tehdään suoraksi, katto näyttää olevan notkolla. Myös sisäkattojen tukipalkit on valikoitu ja veistetty niin, että ne ovat ylöspäin kaarevat eli keskeltä korkeimmillaan. Katon kurkihirsi on päädystä muita vuoliaisia jonkin verran pidemmällä, jolloin katonharjalta saadaan räystäästä jonkin verran pidempi. Se suojaa paremmin päätyseinän keskiosaa. Seinien leveneminen ylöspäin liittyy samaan perinteeseen. Seinien leveneminen rakennuksen tasakertaan on antanut rakennukselle voimaa ja näyttävyyttä. Sen vastakohtana on luhistuva rakennus, jonka seinät ovat kallellaan sisäänpäin. Periaatteeseen on kuulunut paitsi laadukkaan ja tarkoitukseen parhaiten soveltuvan materiaalin valinta, myös sen tietty ylimitoitus. Esimerkiksi hirsirungon alushirreksi on käytetty tukevampaa hirttä, mikä on korostanut rungon kestävyyttä. ${ }^{36}$

Yleisimmät nykyään mainitut liuhaseinäisyyden käytännön syyt liittyvät sateeseen. Liuhaseinäisyyden on katsottu pidentävän talon räystästä ja suojaavan sitä kautta seinää paremmin. Esimerkiksi Ähtävän Kirkonmäen 1621-vuoden riihirakennus ${ }^{37}$ antaa viitteitä rakennustavan lähtökohdista. Rakennuksen sivuseinät ovat suorat, mutta pääty- ja väliseinähirret pitenevät tasaisesti ylöspäin. Niiden varaan on saatu sijoitettua sivuseinän ylimmän hirsikerran ulkopuolelle räystäshirsi, jolla on viety räystäs kauemmas seinästä. Alueellisesti laajimmalle levinnyt liuhaseinäinen rakennustyyppi on niittylato. Se tunnetaan koko Pohjanlahden rannikolla vaikutuspiireineen. ${ }^{38}$ Katolta tuleva vesi tippui kauemmas seinästä ja sadevesikään ei päässyt kastelemaan heiniä siinä määrin kuin suoran seinän läpi. Liuhaseinäinen lato vei vähemmän niittyalaa ja heinät eivät pakkautuneet liian tiiviisti säilyen paremmin. ${ }^{39}$

Liuha seinä suojaa myös hirsien välisiä rakoja sadeveden aiheuttamalta laholta. Pystysuoran hirsiseinän ongelmana on sadeveden pääsy hirsien välisiin rakoihin, jolloin ajan myötä syntyy suuriakin vaurioita. ${ }^{40}$

\footnotetext{
$\overline{36}$ Vreim 1937, 1-2; Sjömar 1988, 76-77.

${ }^{37}$ SLS $373,40$.

${ }^{38}$ Ruotsissa Sigurd Erixon nostaa niittylatojen liuhaseinäisyyden esiin Pohjanlahden ranta-alueille ominaisena rakennustyyppinä. Ne ulottuvat Ruotsissa Pohjois-Uplannista Tornionjokilaaksoon; erityisen yleisiä ne ovat Norrbottenin alueella. (Erixon 1938, 220-224.)

${ }^{39}$ Arnstberg 1976, 82-83. Arnstberg pitää syitä pätevinä, mikäli latojen vinoseinäisyys olisi huomattava. Koska Ruotsissa näin ei ole useinkaan ollut, hän pitää hyötyjä minimaalisina. Arnstbergin tiedossa olevista ruotsalaisista ladoista vanhin vinoseinäinen on vuodelta 1740. (Arnstberg 1976, 72.)

${ }^{40}$ Ks. Kuva 3.
} 
Kuva 3. Sadeveden vaurioittamaa suoraa hirsiseinää. Kuva Matti Mäkelä. MMK.

Hirsien välisiin taskuihin jäänyt sadevesi syö hirteen rappumaisen kolon aina sydänpuuhun asti. Liuha seinä torjuu sadeveden pääsyä rakoihin. SLS:n aineistoista Närpiöstä 1915 saadun tiedon mukaan sahalautojen saatavuuden ja ulkovuorauksen yleistymisen myötä liuhaseinäisyydellä ei ollut seinän suojaamisessa enää niin suurta merkitystä, jolloin suoraseinäisyys yleistyi. ${ }^{41}$

Liuhaseinäisyys vaikuttaa myös huonetilankokemukseen, mikä on todistettu uusissa tutkimuksissa. Esimerkiksi Ruotsissa Karlstadin yliopiston insinööriopiskelijat saivat suunniteltavakseen puhelinkopin avokonttoritiloihin vuonna 2009. Akustisessa suunnittelussa suoria kulmia pyrittiin välttämään, koska ne hajottavat ääntä kaikkein huonoimmin.

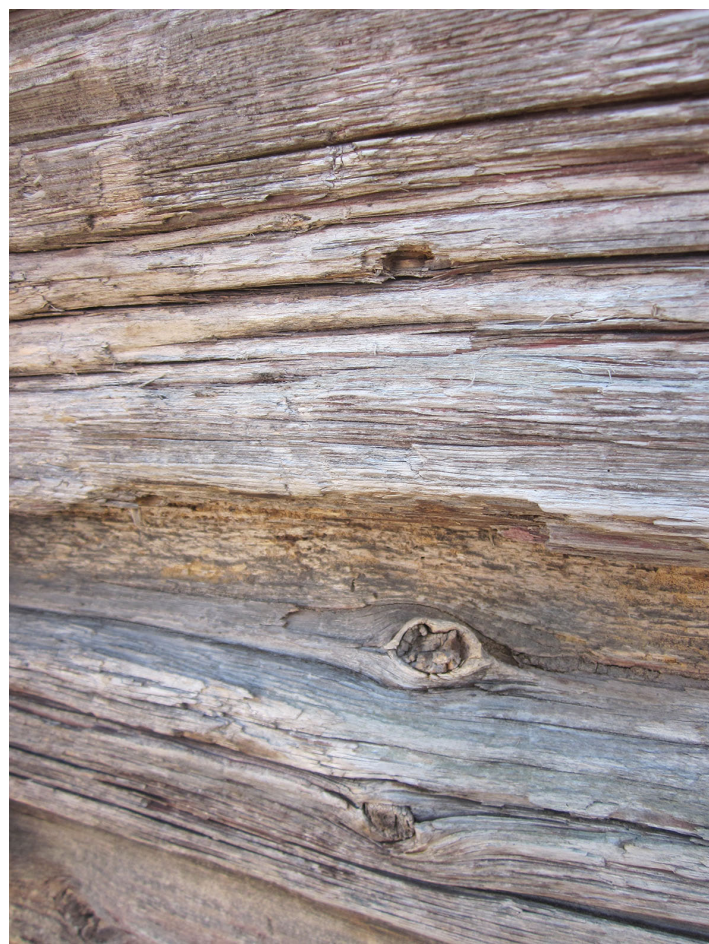

Kaltevat seinät sekä levittävät että keskittävät ääntä, ja hyvään akustiseen lopputulokseen päästään käyttämällä hieman vinoja kulmia. Opiskelijaryhmä työsti ensin kopin, jossa seinät kapenivat ylöspäin äänen heijastuessa lattiaan päin. Kopissa tuntui ahtaalta: "seinät kaatuivat päälle”. Seuraavaksi opiskelijat työstivät kopin, jossa seinät levenivät ylöspäin. Tila säilytti vinot kulmat ja hyvän akustiikan, mutta koppi tuntui paljon tilavammalta. Tila oli anatomisesti oikeassa paikassa, koska ihminenkin levenee ylöspäin eli ylöspäin levenevä tila koettiin luonnollisena ja tilavana. ${ }^{42}$

Liuhaseinäisyys vaikuttaa suoraan myös neliöinä mitattavaan sisätilan kokoon. Liuha rakennus laajentaa yläkerran pinta-alaa. Esimerkiksi tuvan päällä oleva vintti on väliseinää lukuun ottamatta kolmelta seinältä laajempi. Vintin ja alakerran tuvan pinta-alaero riippuu rakennuksen tuvan koosta, seinien liuhuudesta sekä vintin ja tuvan lattiapintojen korkeuksista. Liuhaseinäisessä talossa esimerkiksi 49 neliömetrin kokoisen tuvan yläkerrassa lattia-ala voi olla lähes kaksi neliömetriä laajempi. ${ }^{43}$

\footnotetext{
${ }^{41}$ Sjömar 1988, 77; SLS 257, 185.

${ }^{42}$ Ks. Sandoval, Skoglund \& Nilsson 2009: 20, 26, liite 14; Akustinen suunnittelu huoneen muodon perusteella. http://fi.knaufdanoline.com/wp-content/uploads/Room-shape_FI.pdf

${ }^{43}$ Ks. KUVA 4.; Jos kaksikerroksisen talon sivuseinä on levennyt tasakertaan $15 \mathrm{~cm}$, seinän korkeuden ollessa $570 \mathrm{~cm}$, vintin lattia on ollut alapohjan, tuvan korkeuden ja välipohjan jälkeen noin $380 \mathrm{~cm}$ korkeudella. Tuvan lattia on noin 1/10 -osa korkeudella vintinlattiasta. Vintin lattia on kaksi kolmasosaa seinän korkeudesta ja seinän levetessä tasaisesti, vintin lattian kohdalla seinä on ollut $10 \mathrm{~cm}$ ulompana kuin kivijalan päällä. Koska leveneminen on molemmilla sivuseinillä, vintti on $20 \mathrm{~cm}$ leveämpi. Väliseinän ollessa suora, päätyseinä on liuha laajentaen vinttiä vielä $10 \mathrm{~cm}$. Mikäli kivijalan päällä tuvan aluvarvien sisämitta on $7 \times 7$ metriä, tuvan lattia-ala olisi 7,02 x 7,01 metriä ja vintin pinta-ala on 7,2 x 7,1 metriä eli 1,9 m2 suurempi kuin alakerrassa. Tämä edellyttää suhteellisen suurta liuhaseinäisyyttä.
} 


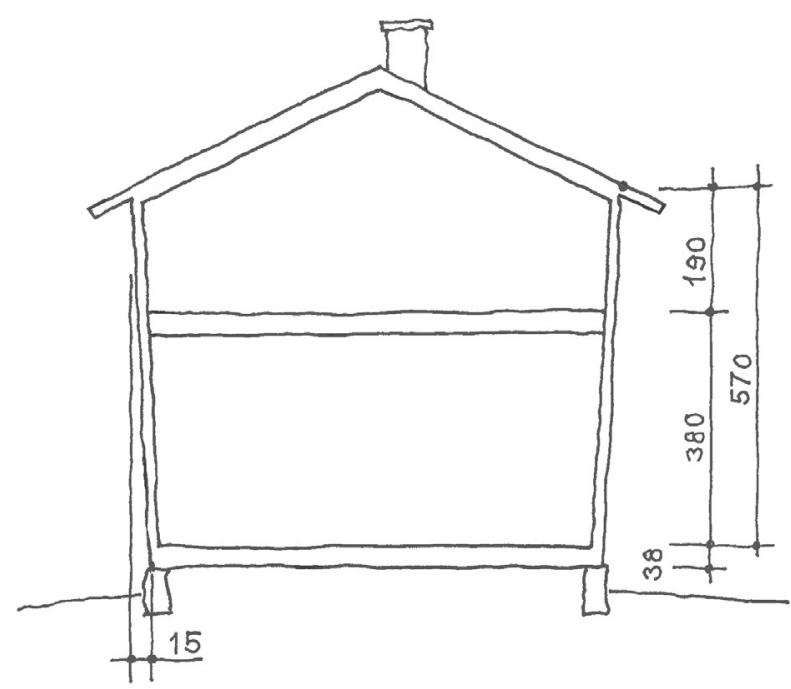

Kuva 4. Mitoitettu leikkaus. Piirros Jaakko Passinmäki. MMK.

\section{Liuhaseinäiset esimerkkitalot}

Säilyneistä liuhaseinäisistä asuinrakennuksista vanhimpia on yksihuoneinen Märijärven savutupa Kuortaneen museoalueella. Sen ikkunaluukkuun on kaiverrettu vuosiluku 1700. Rakennus on ulkoa palhoamaton ja sisältäkin seinät on vain osittain veistetty tasaiseksi. Sisämitoiltaan tupa on noin $640 \mathrm{~cm}$ x $640 \mathrm{~cm}$. Sivuseinät käsittävät 13 hirsikertaa ja päätykolmio seitsemän hirsikertaa. Tuvan taitekaton kattorakenteet eivät ole alkuperäiset, vaan toisesta vanhasta talosta. Rakennuksen peräseinä ja vasen sivuseinä mitattiin alkuperäisten hirsien osalta rakennuksen sisäpuolelta. Peräseinällä hirsikertojen pituusero neljästä yhteentoista oli $7 \mathrm{~cm}$. Sivuseinällä neljännen ja yhdennentoista hirsikerran pituusero on huomattavasti suurempi eli $14 \mathrm{~cm}^{44}$

Märijärven päätyä katsottaessa liuha vaikutelma tuntuu voimakkaalta, vaikka sivuseinien pidennys eli päätyjen kallistus on kaksinkertainen. Rakennuksen päätyseinien ylimpien hirsien katon takia tehty ulosveto luo liuhan vaikutelman, vaikka seinän kaltevuus ei ole yhtä suuri. Räystästä on aiemmin pidennetty 13. seinähirren ulkopuolella olleella räystäshirrellä, joka kompensoi Märijärven tuvassa sivuseinien kallistusta. Rakennuksesta ei ole dendrokronologista ajoitusta, mutta sen piirteet viittaavat siihen, että vuosiluku 1700 voisi olla rakennusvuosi. Mikäli näin on, liuhaseinäisyys on ollut käytössä Pohjanmaan asuinrakennuksissa myös päätyseinillä koko 1700-luvun ajan.

\footnotetext{
${ }^{44}$ Kenttätyöpäiväkirja, 59, MMK.; Ks. LIITE 1. Peräseinällä on uusittu kolme alinta hirsikertaa ja sivuseinällä kaksi. Rakennuksen alimmat hirsikerrat ovat vanhojen aittarakennuksien tapaan pitempiä. Todennäköisesti ne on tehty alkuperäisten hirsien mukaan. Näillä hirsillä lienee ollut jalustarakenteen luonne, mutta kysymys jääköön tässä yhteydessä laajemmin käsittelemättä.
} 
Lapualainen Koivumäen torppa on rakennettu 1700- ja 1800-luvun vaihteessa. Se on perimätiedon mukaan erotettu kahdelle Rinta-Nyrhisen talosta lähteneelle veljekselle, minkä rippikirjat vahvistavat. Rakennuksen tupa on edelleen paikallaan, toinen pääty on siirretty 1850-luvulla myötäjäisinä toisaalle, ja tilalle on rakennettu 1857 porstua ja kamari. ${ }^{45}$ Nuorempi pääty on nurkkaketjuiltaan pystysuora. Vanhempi pääty on huomattavan liuha. Tuvan hirret ovat kookkaat, levein jopa $40 \mathrm{~cm}$ tyvipäästä mitattuna. Torppaa ei tehtäisi näin kookkaasta puutavarasta. Yläkerrassa näkyvät siirtomerkit kertovat rakennuksen vanhan osan siirretyn paikalle. On mahdollista, että Koivumäen tupa on 1690-luvulla perustetun RintaNyrhisen vanhin tupa.

Tupa on sisältä $630 \mathrm{~cm}$ leveä, mutta vain $560 \mathrm{~cm}$ pitkä. Hirsistä rakennetun huoneen neliömäinen perusmuoto on hyvin vakiintunut. Tämä johtaa ajatukseen, että taloa jaettaessa 1850-luvulla tupa olisi pienennetty siirtämällä väliseinää $70 \mathrm{~cm}$ sisemmäksi, jolloin tuvan sivuseinien hirret saatiin ulottumaan ulko-oven pieleen saakka. Tuvan sisäkatto on tasainen ja korkeus $258 \mathrm{~cm}$. Multioinhirret ovat alkuperäiset pyöreät puunrungot. Niiden päällä on kattolautojen kannattajina kahdeksan parrua, joissa on roomalaisilla numeroilla siirtomerkit. Päädyn vasemmanpuoleista nurkkaa ei siirtymisen ja nurkkalautojen kiertymisen vuoksi voinut mitata, mutta oikeanpuoleinen nurkka mitattiin vesivaa'an ja suoran laudan avulla. Nurkka leveni ylöspäin $17 \mathrm{~cm} 311 \mathrm{~cm}$ matkalla. Kun porstuan ovipielestä mitatun tuvan seinähirren paksuus on $18 \mathrm{~cm}$, seinä levenee lähes paksuutensa verran. Saman nurkan päätyseinä kallistuu samalla matkalla hieman vähemmän eli $11 \mathrm{~cm} .{ }^{46}$

Vanhassa Vaasassa Pohjanmaan museolla on Ylistarosta 1957 siirretty Loukolan talo. Talo on ollut paritupa, jonka siirrossa toinen tupa on jätetty pois. Talon tupa on Pohjanmaan vanhimpia, sillä perimätieto kertoo sen olleen Kyrönjoen rannalla jo isonvihan aikana. ${ }^{47}$ Tupa on sisältä avara 8,59 m x 8,64 m ja keskeltä mitattuna peräti $370 \mathrm{~cm}$ korkea. Katto on taitekatto ja sen rakenteet ovat vanhat. ${ }^{48}$

Koska vintillä täytteet nousevat tasakerran yläpuolelle, talo pystyttiin mittaamaan tasakerrasta vain väliseinän porstuan puolelta ja porstuan päädystä. Porstuan pää levenee $18 \mathrm{~cm}$ seinän korkeuden tasakertaan ollessa 4,00 m. Siirtokertomuksessa mainitaan talon keskiosan eli kamarin ja porstuan olevan myöhempää tekoa. Parituvan muodostumishistoriasta kertoo se, että tuvan väliseinä on tasakerrasta lähes $40 \mathrm{~cm}$ leveämpi kuin porstuan pääty. Vanhaan tupaan on liitetty toinen kapeampi tupakehikko yhdistämällä ne väliköllä, jossa oli kamari ja porstua. $^{49}$

\footnotetext{
${ }^{45}$ KS. LIIIE 1; SSHYLapuan rippikirjat IAa:5, 136; IAa:6, 148; IAa:7, 172; IAa:8, 176; Tiedonanto Matti Aila 8.12.2016,

Kenttätyöpäiväkirja 152-153, MMK.

${ }^{46}$ Kenttätyöpäiväkirja, 153, MMK.

${ }^{47}$ Ks. LIITE 1. Talo on sijainnut Ylistaron Topparlan Hiipakkalassa, ensin jokirannassa, josta se on siirretty 250 $m$ itään noin 1825-1850. Isonvihan aikana talon sanotaan säästyneen isännän juotettua venäläisille paloviinaa, jolloin he olivat "unohtaneet" polttaa talon. (Kirje Ylistarosta 18.8.1957, Loukola-kansio, PM.)

${ }^{48}$ Kenttätyöpäiväkirja, 90, MMK; ks. KUVA 5. Multioinhirret ovat kaksi valtavaa puunrunkoa ja niiden ja kahdeksankulmaisten takkihirsien väliin jää tuvan poikki kulkeva poikittaishirsi, piitta, jonka päällä on kaksi multioinhirsiä tukevaa muotoiltua kannatinpylvästä.

${ }^{49}$ Kenttätyöpäiväkirja, 90-91, MMK; Om flyttningen av Matti Loukolas stuga i Ylistaro, Loukola-kansio, PM; Sappinen 1985, 120-125. Porstuan pääty on alhaalta ulkoa $8,61 \mathrm{~m}$ ja tasakerrasta $8,79 \mathrm{~m}$ nurkan sisäpuolelta mitattuna. Vanhan tuvan väliseinän tasakertaleveys on $918,5 \mathrm{~cm}$.
} 
Kuva 5. Loukolan tuvan kattorakennetta. Kuva Matti Mäkelä. MMK.

Loukolan talossa vanhan tuvan pituus alhaalta ja vintin keskeltä on sama $859 \mathrm{~cm}$ eli päätyseinä on suora. ${ }^{50}$ Mahdollinen selitys on, että suoralla päätyseinällä on ennakoitu tuvan jatkamista päätykamareilla tai jollain muulla rakennusrivin osalla. Nykypäivän erillisten rakennusten käsite poikkesi huomattavasti talonpoikaisten hirsiratien ajasta, jolloin oli tapana yhdistellä tarvittavia huoneita pitkiksi rakennusriveiksi. On huomioitava myös rakenteellinen selitys, eli tapa rakentaa pystysuoraa seinää vasten pystysuora seinä ja liuhaa seinää vastaan liuha seinä, koska talokehikossa vastakkainen seinä toimii tasapainottajana ja vastapainona.

Kuortaneen museon päärakennus

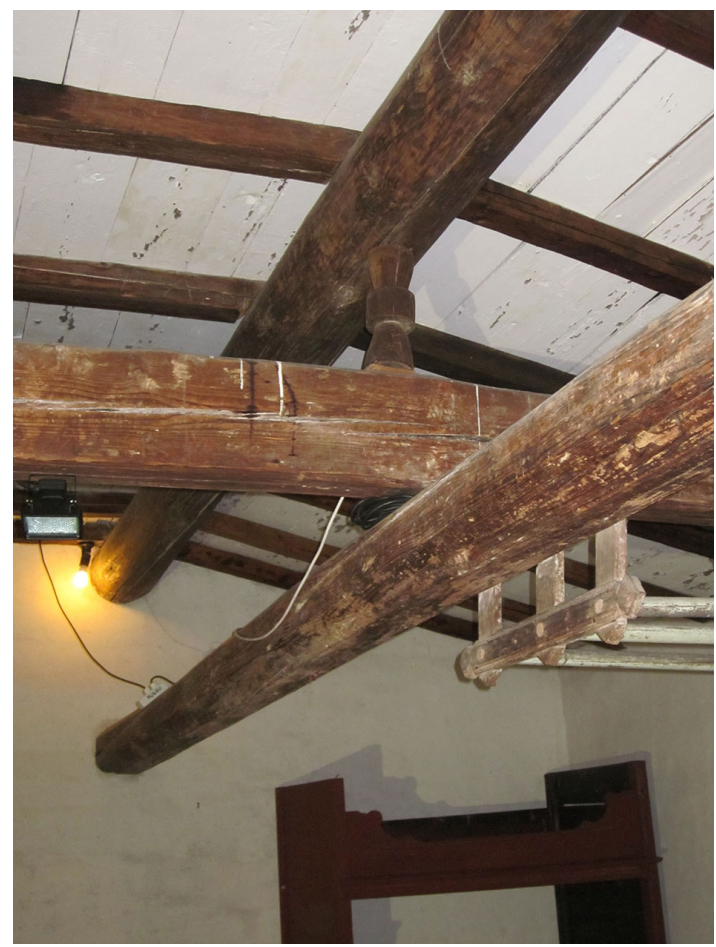
on Keski-Hynnilän talo vuodelta 1774. Rakennus siirrettiin museoksi Kuortaneen Ylijoelta 1958. Talo on Kuortaneelle hyvin tyypillinen korkea puolitoistakerroksinen, jonka seinänkorkeus $540 \mathrm{~cm}$ on hyvin lähellä kaksikerroksisten talojen korkeutta. Tuvan ikkuna-aukkoja on yläosastaan täytetty kaksi hirsikertaa, mikä viittaa rungon korottamiseen. Kooltaan tupa on suuri, leveys $873,5 \mathrm{~cm}$ ja pituus $868 \mathrm{~cm}$. Suuren runkoleveyden vuoksi rakennuksen keskiosan porstuan ja kamarin lisäksi toiseen päätyyn on mahtunut erstuvan sivulle kamari. Tuvassa on taitekatto, jossa multioinhirsien päällä ja niihin tukeutuen kattolautoja kannattavat 10 poikittaissuuntaan kulkevaa viiden tuuman kattoniskaa. Keskituvan sisäkorkeus on peräti $350 \mathrm{~cm}$. Keski-Hynnilässä päätyseinä on ylhäältä sentin kauempana väliseinästä kuin alhaalta eli päätyseinä on käytännöllisesti katsoen pystysuorassa. Keski-Hynnilän tupa levenee sivuseiniltään tasakertaan $17,5 \mathrm{~cm}$, minkä havaitsee parhaiten talon sisäpuolella vintin nurkkia katsottaessa. ${ }^{51}$

Latva-Talvitie Lapuan Alapäässä siirrettiin Jalasjärven Luopajärven Kettulasta vuonna 2005. Ruotsin ajan lopulla rakennettu talo edustaa vanhimmassa muodossaan kolmihuoneista, tuvan, kamarin ja porstuan yhdistelmää. Rakennus siirrettiin ensimmäisen kerran 1830 ja siihen rakennettiin samalla pohjakaavalla yläkerta 1831. Tuolloin rakennusta korotettiin kahdeksalla kookkaalla hirsikerralla. Taloa jatkettiin 1869, jolloin alakertaan tehtiin porstuakamari ja peräkamari. Tuolloin yläkertaan rakennettiin ylähätupa, jonka päällä on oma kattopalkistonsa.

\footnotetext{
${ }^{50}$ Kenttätyöpäiväkirja, 88, 90-91, MMK; Kirje Ylistarosta 18.8.1957, Loukola-kansio, PM.

${ }^{51}$ Ks. LIITE 1; Kenttätyöpäiväkirja, 88, MMK. Keski-Hynnilän tuvan päätyseinän sisämitta kivijalanpäältä on $873,5 \mathrm{~cm}$ ja tasakerrasta mitattuna $891 \mathrm{~cm}$.
} 


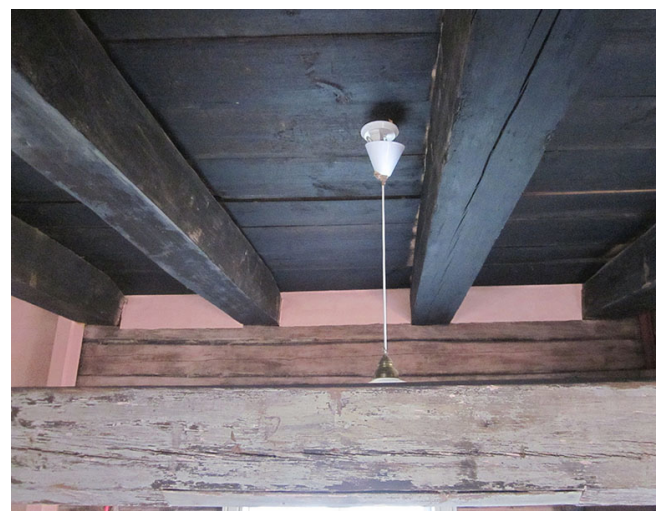

Kuva 6. Latva-Talvitien tuvan kattoniskoja. Tuvan keskimmäinen kattoniska (vas.) on lattiasta 1,5 cm päädyn kattoniskaa (oik.) alempana. Vastapäisellä seinällä ero on 1,2 cm. Kuva Matti Mäkelä. MMK.

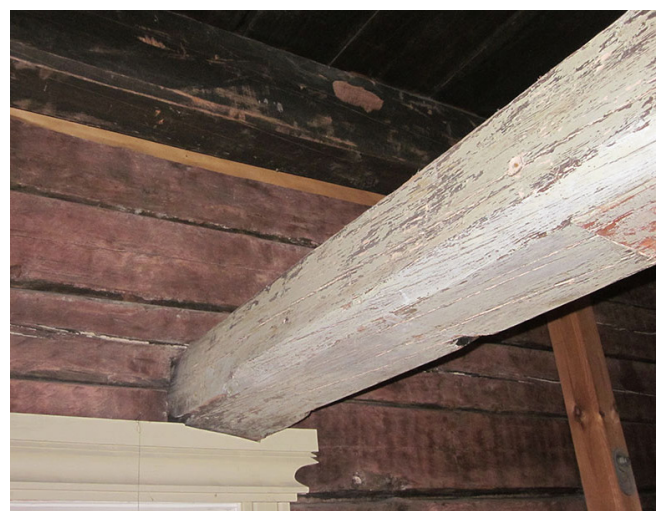

Kuva 7. Latva-Talvitien tuvan vasen takkihirsi kääntyneenä keskiföljäriä kohti. Kuva Matti Mäkelä. MMK.

Latva-Talvitie on sivuseiniltään $575 \mathrm{~cm}$ korkea, kaksikerroksinen pohjalaistalo. Sen vanhempi tuvanpääty levenee tasakertaan $27,5 \mathrm{~cm}$. Latva-Talvitien tupa on kooltaan $711,5 \mathrm{~cm}$ x 710,5 cm, sisäkorkeudeltaan $310 \mathrm{~cm}$, ja sen katto on alkuperäinen. Kattolaudat on ladottu kahdeksan poikittaissuuntaan kulkevan, noin 8-9 tuumaisen kattoniskan päälle. Talon uudempi pääty on ikkunaton ja sen liuhuus on $23,5 \mathrm{~cm}$ eli $4 \mathrm{~cm}$ toista päätä vähemmän. ${ }^{52}$ Ylähätupaa laajennettiin talon keskiosaan siirtämällä väliseinäksi muuttunut vanha päätyseinä yläkerran osalta metrin päätupaa kohti, jolloin seinä samalla suoristettiin. Alakerrassa liuhaseinäisyyttä on jonkin verran edelleen havaittavissa, sillä kamarinseinän pintoja tehtäessä kyseistä seinää jouduttiin listoilla jonkin verran koolaamaan. ${ }^{53}$

Tuvan päätyseinä kallistuu tasakerran korkeudelle peräti $23 \mathrm{~cm}$ eli mitta ylittää seinänpaksuuden. Tuvan väliseinä on ollut suora ja sitä on tukenut kamarin ja porstuan välinen seinä. Koska kamari ja porstua ovat noin $250 \mathrm{~cm}$ tupaa lyhyempiä ${ }^{54}$, rakennuksen väliseinä on vintillä kallistunut liuhaa päätyä kohti. Liuhat päätyseinät eivät ole olleet samalla etäisyydellä väliseinästä, jolloin vastapaino ei ole ollut sama. Latva-Talvitiessä mitattiin tasakerrasta vintin leveys väliseinän kohdalta, keskeltä ja päädystä. Vintti oli keskeltä $4 \mathrm{~cm}$ ja päädystä $2 \mathrm{~cm}$ leveämpi kuin väliseinän vierestä mitattuna. Päätyseinä oli keskeltä myös kauempana väliseinästä kuin nurkat. Mittaus paljastaa hirsiseinän käyttäytymisen ja nurkan merkityksen seinien sitomisessa. ${ }^{55}$

\footnotetext{
${ }^{52}$ Ks. LIITE 1; Kenttätyöpäiväkirja, 86-87, MMK. Latva-Talvitien vintin tasakertahirsien etäisyys on $739 \mathrm{~cm}$, leveyden ollessa alhaalta $711,5 \mathrm{~cm}$. Mitta väliseinästä päätyyn on alhaalla tuvassa $710 \mathrm{~cm}$ ja tasakerrassa, vintin päätyikkunan yläpuolella $733 \mathrm{~cm}$. Talon 1869 tehty toinen pää on tasakerrasta leveydeltään $735 \mathrm{~cm}$ ja kivijalan päältä $711,5 \mathrm{~cm}$.

${ }^{53}$ Kenttätyöpäiväkirja, 21, MMK.

${ }^{54}$ Kenttätyöpäiväkirja, 21, 86-87, MMK.

${ }^{55}$ Kenttätyöpäiväkirja, 87, MMK. Vintti oli kapeimmillaan $737 \mathrm{~cm}$ väliseinän vieressä, leveimmillään $741 \mathrm{~cm}$ seinän keskellä ja päädyssä $739 \mathrm{~cm}$. Vintti mitattiin tasakerran korkeudelta myös pituussuuntaan, väliseinästä vasempaan nurkkaan $732 \mathrm{~cm}$, keskelle päätyikkunan yläpuolelle $733 \mathrm{~cm}$ ja oikeaan nurkkaan $731 \mathrm{~cm}$.
} 
Latva-Talvitien tuvassa on näkyvissä myös merkkejä seinän painumisesta. Seinän keskiosa johtaa kuivumista, mikä näkyy tuvan sisällä keskiosan kattoniskojen painuessa alimmaksi. ${ }^{56}$

Voimista saa myös käsityksen tuvan päätyseinässä olevia takkihirsiä katsomalla. Takkihirsien päät ovat kääntyneet seinän keskiosan voimakkaasta painumisesta johtuen runsaasti sisäänpäin. ${ }^{57}$

\section{Liuhaseinäisyyden jäljillä}

Ruotsissa talonpoikaistalojen suurimpien huoneiden koko on tyypillisesti 6 × 6 metriä. Seinän pituuden ylittäessä kuusi metriä ja seinän korkeuden ylittäessä 2,2-2,5 metriä, on vaadittu yleensä seinää jäykistäviä vahvistuksia. ${ }^{58}$ Pohjalaisten asuinrakennusten suurimmat huoneet ovat rannikkoa lukuun ottamatta tyypillisesti 7 × 7 metriä ja kolmen metrin tuvan korkeuskaan ei ole poikkeuksellista. Suuret ja korkeat huoneet ovat aina alttiita muutoksille, kun etäisyys nurkkaketjuihin kasvaa. Esimerkkitalojen perusteella voidaan kuitenkin sanoa, että liuhaseinäisyys on todennäköisempää asuinrakennuksissa, joiden päädyissä on suuria ja korkeita huoneita. Tällainen on Pohjanmaalla yleinen, vanha paritupatyyppi.

Kulttuurihistorioitsija Sigurd Erixon on ajoittanut talonpoikaisen parituvan varhaiset esimerkit Ruotsissa 1600-luvun jälkipuolelle, Södermanlandista 1640-luvulle. ${ }^{9}$ Tilojen halkomisten seurauksena Ruotsissa alettiin joillakin alueilla siirtyä muihin pohjakaavatyyppeihin jo 1700-luvun jälkipuolella, vaikka parituvan levinneisyys oli siellä alueellisesti laajimmillaan 1800-luvulla. ${ }^{60}$ Useimmissa vanhoissa ruotsalaisissa parituvissa kiinnittää huomiota matala seinäkorkeus. Vaikka aikojen saatossa pohjalaistaloja on usein korotettu, ne vaikuttavat alun perinkin olleen useimpia ruotsalaisia sisariaan korkeampia. Tämä saattaa johtua savutupien vanhasta perinteestä, joka edellytti suurempaa huonekorkeutta. ${ }^{61}$

Vanhemmissakin pohjalaistaloissa on suoraseinäisiä asuinrakennuksia, kuten Jalasjärven museon kaksikerroksinen pohjalaistalo. Rakennus edustaa keskitupaista mallia, jossa kamarit

\footnotetext{
${ }^{56}$ Ks. Kuva 6 Latva-Talvitie. Kuvassa vasemmalla näkyvä seinän keskellä oleva niska on oikeanpuoleista päätyniskaa lattiasta 1,5 cm alempana. Saman seinän lähimpänä väliseinää oleva niska on lattiasta $3,8 \mathrm{~cm}$ keskiniskaa korkeammalla. Toisella seinällä ero on vielä suurempi, mutta mitta ei ole vertailukelpoinen, koska kyseisessä nurkassa ei ole lankkulattiaa. (Kenttätyöpäiväkirja, 84, MMK.) Vaikuttaa siltä, että lähimpänä vintinovea oleva kattoniska on tehty korkeammalle, koska on pyritty helpottamaan vintille menoa. Keskellä ja päädyssä olevien kattoniskojen korkeuseron voi ajatella tulleen painumisen ja kutistumisen kautta.

${ }^{57}$ Ks. Kuva 7 Latva-Talvitie. Vasen takkihirsi on oikeasta alareunastaan vasenta alareunaa $4 \mathrm{~cm}$ alempana ja sen etäisyys seinän keskellä olevaan följäriin on $75 \mathrm{~cm}$. Oikea takkihirsi on kääntynyt keskelle vähemmän; vasen alareuna on oikeaa $1 \mathrm{~cm}$ alempana. Sen etäisyys keskelle on $175 \mathrm{~cm}$ eli se on metrin kauempana päätyseinän keskikohdasta.

${ }^{58}$ Andersson 2016, 51.

${ }^{59}$ Erixon (1947)1982, 291. Erixonin ajoituksia on myös kritisoitu liian varhaisina. (Arnstberg 1976, 75.)

${ }^{60}$ Erixon (1947)1982, 288.

${ }^{61}$ Ks. Valonen 1994, 18. Värmlannissa, Mattilan savutuvassa tehdyissä tutkimuksissa savu leijaili noin 220 cm:n korkeudesta ylöspäin eli ihmiset pystyivät oleskelemaan tuvassa savupatjan alapuolella. Näkyvää savua oli vain ensimmäisen lämmitystunnin aikana ja $160 \mathrm{~cm}: n$ korkeudelta mitatut häkäarvot pysyivät raja-arvojen alapuolella koko lämmityksen ajan. (Ks. Nilsson 2013) Tämä lämmitysmukavuus edellytti savutuvassa kuitenkin kohtuullisen suurta huonekorkeutta, mikä saattoi kulttuurisesti heijastua myös uloslämpiävien tupien huonekorkeuteen.
} 
ovat rakennuksen päädyssä. Voidaan ajatella, että hirsisessä asuinrakennuksessa ulkoseinät on tehty liuhoiksi. Hirsirungon kokonaisuuden kannalta väliseinillä ja välipohjan palkistolla on kehikkoa tukeva rooli. Mikäli tuvan jatkoksi on tehty päätykamarit, päätyseinä saa tuekseen kamarien välisen seinän. Jos pohjakaavaa sovelletaan myös yläkertaan, koossa pidettävän seinän pinta-ala pienenee olennaisesti. ${ }^{62}$

Tämä selittää, miksi esimerkiksi Jalasjärven museo on suoraseinäinen. Pohjakaava pienentää rakennuksen suuret seinäpinta-alat minimiin, minkä vuoksi liuhaseinäiselle rakennustavalle ei ole ollut tarvetta. Keskitupaisista pohjalaistaloista löytyy kuitenkin myös liuhaseinäisiä taloja, kuten Vetelin Salmelan (ent. Löijan Alitalo) kaksikerroksinen talo. ${ }^{63}$ Pohjakaava ei siis yksinomaan ratkaise, tehdäänkö rakennus liuhaksi vai ei. Alueellinen rakennustapa on eräs selittävä tekijä, mutta ratkaisu voi löytyä myös ulkoseinien ja väliseinien erosta. Rakennuskonservoinnin yliopettaja Matti Laine toteaa ulkoseinien olevan säiden vuoksi jatkuvassa muutoksessa, välillä ne kuivuvat, välillä turpoavat kosteuden vaikutuksesta. Hirren kutistumista ja palautumista on vaikea seurata. ${ }^{64}$ Väliseinät ovat kuitenkin kuivemmissa olosuhteissa ja painuvat ulkoseiniä enemmän. Viisi metriä korkeassa seinässä väliseinien etumatka painumisessa olisi $5 \mathrm{~cm} \cdot{ }^{65}$ On mahdollista, että jotkut rakentajista käyttivät liuhaseinäisyyttä tehostamaan ulkoseinien painumista.

Lämpimän hirsirakennuksen rakentajat ovat aina pyrkineet kehikon tasaiseen painumiseen. Nykyään erilaisilla liimaustekniikoilla pyritään ehkäisemään puun kutistumista eli pyritään puun "kivettämiseen". Entisajan hirsirakentajat käyttivät puun luonnollisia ominaisuuksia tiiviin rakenteen aikaansaamiseen. Painumisen avulla huolellisesti varatusta hirsirungosta saatiin tiivis ja lämmin rakennus. Vuonna 1957 julkaistussa rakentamisen oppikirjassa kehotetaan välttämään kaksikerroksisen hirsirakennuksen rakentamista, koska rakennuksen laskeutuminen ja siitä mahdollisesti aiheutuvat yllätykset ovat vaikeasti arvioitavissa. ${ }^{66}$ Tämä ei ollut ongelma 1700-luvun Pohjanmaalla tai Norjassa.

Kuten 1800-luvun lopun rautatierakennuksia tutkinut Janne Jokelainen on todennut, valtaosa hirsirakenteen muutoksista syntyy ensimmäisen 3-4 vuoden painuma-aikana, jolloin rakenteen oma ja ulkoinen kuormitus tiivistävät liitosten väljyydet. Painuman tasaisuus on

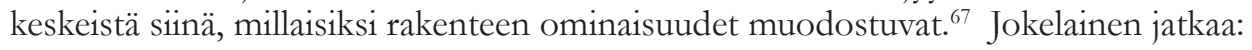

\section{Onkin ilmeistä, että hirsirungon paras tekninen toiminta saavutetaan runkomuodolla, joka pystytään toteuttamaan pubtaalla lamasalvosrakenteella, ilman mitään erikoisrakenteita. ${ }^{68}$}

\footnotetext{
${ }^{62}$ Etelä-Pohjanmaan Järviseudulla on taloja, missä keskiakselilla oleva pitkittäinen väliseinä ulottuu lähes talon harjalle asti. Tämä piirre johtuu siitä, että muuten vaikeasti tapeilla kasattava kiita eli seinän päätykolmio saatiin tuettua ylös asti keskeltä, jolloin päätykolmio puolittui, tappien määrä voitiin minimoida ja kolmio pysyi paikallaan väliseinän, harjahirren ja parin vuoliaisparin avulla.

${ }^{63}$ Ks. Marttilan remontti. http://salmelankartano.fi/marttila-remontin-alla/

${ }^{64}$ Tiedonanto Matti Laine 12.1.2018, Kenttätyöpäiväkirja, 147, MMK. On myös huomioitava, että kuusi imee vettä huonommin kuin mänty, ja siksi kosteuden aiheuttamat liikkeet ovat siinä hitaampia. (Puurunen 1995, 4.)

${ }^{65}$ Väliseinät painuvat noin $10 \mathrm{~mm}$ ulkoseiniä enemmän korkeusmetrille, koska sisällä kosteutta vähemmän. (Koponen 2011, 14; Roininen (1957) 1971, 45.) 1900-luvun alussa hyvälaatuisesta hirrestä tehty talo painui 1,8 cm seinänkorkeusmetrille. Nopeasti kasvaneella puulla painuminen on luonnollisesti suurempaa. Sjömarin informanttien mukaan painuminen on kevään kuivuneella hirrellä 1,7 - 2,7 cm seinän korkeusmetrille. (Sjömar 1988, 65.)

${ }^{66}$ Roininen (1957) 1971, 30.

67 Jokelainen 2007, 92-93.

68 Jokelainen 2007, 92-93.
} 
Rakennustutkija Peter Sjömarin mukaan seinälevyn jäykkyys riippuu nurkkasalvosten, karojen, tappien ja varauksen kyvystä sitoa hirsikerrat yhteen. Seinä voidaan aina helposti vahvistaa följärillä. Sjömarin mukaan painumisen yhteydessä vaikuttavat suuret voimat, jolloin tapittomassa rakennuksessa hirret liukuvat; tapitettu rakennus jäykistyy suorakulmaisesti paikoilleen. Hirsirakennusta on Sjömarin mukaan vaikea selittää teoreettisilla malleilla, koska rakenteet vaikuttavat usealla tavalla. Esimerkiksi nurkkasalvokset voivat Sjömarin mukaan vaikuttaa rakenteessa joko nivelenä tai jäykkänä sidoksena. ${ }^{69}$

Tärkein hirsiseinää koossa pitävä elementti on nurkkasalvos. Nurkkasalvos on tehty perinteisesti tiiviiksi, sillä sen on pitänyt vastustaa mahdollisia seinässä tapahtuvia muutoksia. Seinän jäykkyys perustuu siis tiiviiseen nurkkasalvokseen. Nurkkaa tehtäessä käytettiin myös erityistä nurkkavaraa, joka oli eri työkalu kuin seinävara. Mikäli nurkasta teki väljän, siitä seurasi hirsirakentaja Seppo Kalliokosken mukaan vaikeuksia puun kuivuessa. Ajan myötä nurkka väljentyy ja haristuu joka tapauksessa. Seinän kallistaminen on tehty Kalliokosken mukaan nurkkasalvoksen eli rakenteen saranan tukemiseksi. Kalliokoski toteaa, että vinouden ei ole tarvinnut olla suuri, kun se jo vaikuttaa rakenteen jäykkyyteen. Kalliokosken mukaan liian jäykkiä rakenteita pyrittiin ennen välttämään, koska rakennusosan jäykistäminen aiheuttaa ketjureaktion eli jäykistämistarpeen jonnekin muualle. Liuhan seinän hän toteaa lähestyvän muodoltaan rakentamisessa paljon tukena käytettyä kolmiorakennetta. ${ }^{70}$

Seinä jakaa ylhäältä tulevan kuormituksen vinon geometriansa mukaisesti siten, että rakennuksen peruskiviin vaikuttaa sekä pystysuuntainen että vaakasuuntainen voiman komponentti. ${ }^{71}$ Pystysuora voima painaa rakennusta maahan, vaakasuora puristaa rakennetta sisäänpäin.

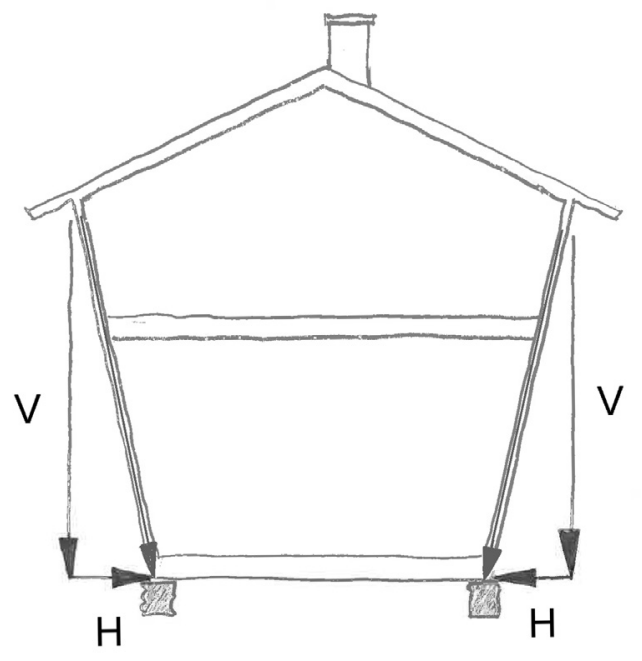

Kuva 8. Voimakomponenttikuva. Piirros Jaakko Passinmäki. MMK.

\footnotetext{
${ }^{69}$ Sjömar 1988, 73-75.

70 Tiedonanto Seppo Kalliokoski 16.12.2016, Kenttätyöpäiväkirja, 74-76, MMK.

${ }^{71}$ Ks. Kuva 8. Voimakomponenttikuva. Rakennusinsinööri Jaakko Passinmäen suorittamien arviolaskelmien
} 
Eräs tapa havainnollistaa seinän kallistamisen aiheuttamia voimia on ottaa toista käsistä kiinni ja nojata hieman taaksepäin. Kädet ovat sivuseiniä sitovat päätyseinät ja palkisto. Kallistus aiheuttaa ylävartaloon voimakkaan jännitteen ja jalkapohjat liimautuvat tiukasti lattiaa vasten. Vastapaino pitää tukevasti ryhdissä ja kehon paino ohjautuu jalkojen kautta tukevasti lattiaan. Ajatellaan jalkojen olevan rakennuksen nurkkaketjut ja niiden alla olevan lattiapinnan nurkkakivet. Näin vinoseinäisyys kiilasi rungon tiukemmin nurkkakiviä vasten. Talon alla oleva maa, kellareineen ja multipenkkeineen oli hyvin kuiva, kun taas seinän ulkopuolella oleva maa oli erittäin kosteaa ja altista routimiselle. Liuhaseinäisyyden ansiosta rakennuksen runko pysyi perustuksen liikkeitä vastaan tiukemmin paikoillaan ${ }^{72}$.

Jos neljä ihmistä nousee kulmittain sopivalla etäisyydellä olevien nurkkakivien päälle ja ottaa toisiaan käsistä kallistuen taaksepäin, saadaan vaikutelma liuhaseinäisestä rungosta. Jos käsien liitoskohtaan eli seinän keskelle lisätään paino, lisäys tuntuu erityisesti selkärangassa eli rakennuksen nurkkaketjussa.

\section{Loppupäätelmiä}

Tämän artikkelin tutkimustehtävänä oli selvittää, mitkä tekijät selittävät liuhaseinäistä rakentamistekniikkaa Pohjanmaalla ennen 1800-luvun loppua. Tutkimuksen perusteella on tunnistettu erilaisia asuinrakennuksen liuhaseinäisyyden rakenteellisia selityksiä.

Ensimmäinen liuhaseinäisen rakentamistekniikan selitys on, että sillä on jäykistetty rakennuksen runkoa tavalla, joka ei ole vaarantanut rakennuksen tiivistymistä eli painumista. Liuhaseinäisissä pohjalaistaloissa seinän kiristäminen on toteutettu tuoreen puun kutistumisen avulla. Koska nurkat ovat muodostuneet hirsien kaulaosista, joissa sydänpuun osuus on korkea, nurkat ovat painuneet vähemmän kuin seinän keskiosa, missä on paljon pintapuuta. Kaukana nurkista oleva seinän keskiosa johtaa painumista eli tiivistyy alaspäin. Tapittomassa seinässä tätä kutistumisen aiheuttamaa liikettä ei ole rajoitettu, mikä johtaa seinän kiristymiseen. Tämä tapahtuu ylhäältä alaspäin, sillä ylimmän hirren keskikohta on kauimpana nurkista. Seinän kiristyminen vaikuttaa myös rakennuksen selkärangoissa eli nurkkaketjuissa. Kallistetut nurkkaketjut pistekuormineen pystyvät melko hyvin vastustamaan seinän keskellä tapahtuvaa painumista, mikä puolestaan lisää seinän kiristymistä. Tämä tapahtuu puhtaan lamasalvostekniikan avulla, ilman ylimääräisiä rakenneosia tai puun liikkeen rajoittamista.

Toinen tärkeä rakenteellinen syy liuhaseinäiseen rakentamiseen liittyy talon perustuksiin. Liuhaseinäisessä talossa katon ja rungon paino suuntautuu nurkkakiviin pistekuormana nurkkaketjun kautta. Rakentamalla seinät vinoon, ylhäältä tulevaa vertikaalista voimaa jaetaan osin horisontaaliseksi eli vaakasuuntaiseksi voimakomponentiksi. Vaakavoimakomponentit vaikuttavat alimman hirren tasolla sekä päädyn että pitkän sivun suunnalta rakennuksen sisään päin, jolloin rakennuksen runko pysyi perustuksen liikkeitä vastaan tiukemmin paikoillaan. Koska perustukset olivat usein hirsirakennusten ongelmakohta, liuhaseinäisyydellä

\footnotetext{
mukaan vaakavoiman suuruusluokka on noin 100-150 kg/m, kun seinän liuhuus on 4-5 cm/metri. Perustustasoon vaikuttavan vaakavoiman suuruus saadaan suoraan vinon seinälinjan ja kuvassa esitetyn pysty- ja vaakakomponentin muodostamasta geometrisesta kolmiosta. Vaakakomponentin pituus jaettuna kolmion hypotenuusan eli vinon seinän pituudella kerrottuna perustustasoon tulevalla kuormituksella. (Sähköpostitiedonanto Jaakko Passinmäki 9.12. ja 15.12.2019, Kenttätyöpäiväkirja 92-93, MMK.)

72 Tiedonanto Markus Romppala 10.9.2018, Kenttätyöpäiväkirja, 63, MMK. Tieto on peräisin hänen kirvesmiehinä toimineilta isältään ja isoisältään.
} 
saatiin rakennekokonaisuus vakaammaksi siellä, missä sitä eniten tarvittiin. Runko on jäykimmillään alhaalla, missä se on kapeimmillaan. Rungon väljemmässä osassa, tasakerrassa, ongelmat vältettiin painumisen avulla. Seinän keskiosan voimakas painuminen antoi nurkkaketjuille suunnan sisäänpäin kiristäen rakenteen, jolloin rakennus pysyi tiiviisti koossa.

Nämä rakenteelliset syyt ovat vastaus alussa esitettyyn tutkimuskysymykseen. Ne ovat 150 vuoden aikana unohtuneet rakentamistekniikan muuttuessa. Muut liuhaseinäisyyden syyt ovat olleet ilmeisempiä ja eläneet sen vuoksi pidempään. Kaikki artikkelissa käsitellyt liuhaseinäisyyden syyt ovat kuitenkin vastauksia tutkimuskysymykseen eli perusteita rakennustavan käytölle. Liuhaseinäisyyden syyt havainnollistavat perinteisen rakentamistavan kokonaisvaltaisuuden. Yhdellä tarkoituksenmukaisella rakennustavalla pystyttiin huolehtimaan rakenteessa lukuisista tehtävistä.

Tunnetuimmat syyt, räystään pidentäminen tai ulkoseinän rakojen suojaaminen sadevedeltä ovat olleet päteviä syitä rakenteen käyttämiselle, etenkin aikana ennen ulkovuorauksen yleistymistä. Eri alueiden ja rakentajakoulukuntien suhde ilmiöön on ollut erilainen. Pohjakaavojen kehittyessä jotkut rakentajakoulukunnat ovat saattaneet käyttää rakennustapaa myös ulkoseinien painumisen tehostamisessa, millä on pyritty ottamaan kiinni kuivempien sisäseinien painumista.

Edellä mainittujen syiden lisäksi liuhaseinäisyys vaikuttaa tilan kokemiseen, sillä ylöspäin levenevä seinä lisää tilan tuntua. Rakennustapa kasvattaa myös yläkerran neliöitä. Pinta-alaero riippuu liuhuudesta, huoneiden koosta sekä kerrosten lattiakorkeuksista. Seinien leveneminen muuttaa myös huoneen kulmia. Koska suorat kulmat hajottavat ääntä huonoimmin, liuhaseinäisyys parantaa myös tilan akustiikkaa.

Liuhaseinäisyyteen on vaikuttanut myös rakennusten voimaa ja näyttävyyttä korostanut estetiikka. Siitä Halvor Vreim on Norjassa käyttänyt nimitystä "soliditetskravet", vakavaraisuusperiaate. Siinä rakennuksen linjoilla pyrittiin työskentelemään luhistumista vastaan ja periaatteisiin kuului myös liuhaseinäisyys. Sama estetiikka vallitsi Norjassa niillä alueilla, missä liuhaseinäisiä taloja esiintyi. Tiettävästi norjalaisten kaksikerroksisten talojen leveneminen tasakertaan on ollut noin $20 \mathrm{~cm}$. Pohjanmaalla seinän paksuus vaikuttaa olleen alkuperäinen mitta pohjalaistalon seinän levenemiselle. Liuha pohjalaistalo on levinnyt kaksi kertaa seinän paksuuden eli kuuden tuuman seinällä $30 \mathrm{~cm}$. Rakennustapa on kehitetty alueella korostetusti huippuunsa, ja se on vanhan pohjalaistalon leimallisin piirre. Seinän kallistus on muuttunut ajan myötä ja vaihdellut rakennuskohtaisesti, mutta rakennustapana se on ollut Pohjanmaalla yleinen.

Hirsirakennuksen liuhaseinäisyys näyttää yleistyneen Pohjanmaalla 1600-luvulla. Rakennustavan lähtökohtana vaikuttaa olleen räystään pidentäminen, jota on ensin tavoiteltu päätyseinähirsien pidentämisellä, mihin Ähtävän riihi viittaa. Tätä tukee se, että Keski-Hynnilässä ja Loukolassa vain sivuseinät ovat liuhoja, jolloin rakennusta on ollut helppo jatkaa. Pääty- ja väliseinien hirsikolmioiden voi ajatella tehostaneen seinien keskiosan painumista. Märijärven tupa kuitenkin osoittaa liuhaseinäisyyttä käytetyn kaikilla seinillä jo yksihuoneisessa asuinrakennuksessa. Ei ehkä ole sattumaa, että Märijärven tupa on jäänyt liuhojen päätyseiniensä vuoksi yksihuoneiseksi. Koivumäessä ja Latva-Talvitiessä 1850- ja 1860-lukujen muutoksissa on siirretty ja suoristettu väliseiniä tai väliseiniksi muuttuneita seiniä.

Koivumäki ja Loukola ovat olleet paritupia, joista toinen tupa on poistettu. Liuhaseinäisyyden voi katsoa soveltuneen hyvin paritupatyypille, jossa suuret seinäalat ovat rakennuksen päissä. Symmetristä paritupaa on käytetty runsaasti Etelä-Pohjanmaalla, sekä lyhyellä 
että pidemmällä keskiakselilla. ${ }^{73}$ Alun perin parituvaksi tehdyissä rakennuksissa suoraseinäisen keskiakselin voi ajatella toimineen laajennettuna tukipilarina päiden liuhoille seinille. Vaikuttaa siltä, että myös hirren pelkkaaminen ja uloslämpiävät takkamuurit yleistyivät samoihin aikoihin liuhaseinäisyyden ja paritupatyypin kanssa.

Liuhuus näyttää korostuvan taloissa, joissa välipohjan palkisto on tasainen. Latva-Talvitien tuvassa vankka poikittaisniskoitus vie välipohjan painon sivuseinille. Eniten levenevän Koivumäen niskoitus on tasainen, vaikkakin multioinhirsien päällä, jotka ohjaavat välipohjan painoa myös päätyseinälle. Taloissa, missä tuvan sisäkatto on taitekatto ja sivulaipiot laskevat jyrkästi sivuseiniä kohti, liuhuus vaikuttaa olevan vähäisempi. Tupien sisäkattorakenteita, niiden ikäkerrostumia ja toimivuutta pitäisi tutkia. Ne ovat yhteydessä rungon tasaiseen painumiseen, liuhaseinäisyyden ollessa siinä yksi osatekijä.

Pohjalaisten kirvesmiesten osaamisen nähdään usein olleen seurausta laivanrakennuksesta, mutta liuhaseinäisyyden kehittymiselle on olemassa varhaisempikin mahdollisuus. Mikäli kodan jalustarakenne on ollut joillain alueilla liuha, ja Kustaa Vilkunan teoria kodan jalustarakenteen vähittäisestä kasvamisesta hirsirakennukseksi on oikea, liuhaseinäisyys voi periytyä jo Pohjanmaan jokivarsien talvikylien kiinteän asutuksen vakiintumisvaiheesta.

Liuhaseinäiset talot on usein veistetty kehikoksi jo metsässä ja jätetty kuivumaan pitkäksikin aikaa. Tällöin maksimoitiin seinän tiivistyminen kutistumisen avulla ja rakennuksen katto, aukotukset ja niihin liittyvät tapitukset tehtiin vasta kun hirret tuotiin varsinaiselle rakennuspaikalle. Tapa vaikuttaa hävinneen vähitellen 1800-luvun aikana.

Rakennusten korkeuden kasvaessa liuhan seinän käyttö levisi Pohjanmaalla lukuisiin rakennustyyppeihin. Liuhaseinäisyys vaikuttaa olleen 1600-luvun pohjalainen innovaatio, joka saattoi kirkkorakentamisessa osittain korvata tukipilarin kuormia siirtävää ja jäykistävää vaikutusta, jolloin säästettiin monen nurkkaketjun tekeminen. Tukipilareista luovuttaessa siirryttiin kahdeksankulmaisiin ja myöhemmin ulko- ja sisäviisteisiin ristikirkkoihin, missä nurkat eivät olleet enää 90 asteen kulmassa. Ristikirkossa ei ylipäätään tarvinnut valtavan pitkiä seinähirsiä suhteellisen suuren tilan aikaansaamiseksi. ${ }^{74}$ Kirkollisista 1600 -luvun rakennuksista Tornion tapuli ja Koivulahden kirkko ovat olleet kahdeksankulmaisia ja voimakkaasti liuhaseinäisiä. Keskieurooppalaisesta rakentamisesta lähtöisin olevia tukirakenteita käytettiin muun muassa ruotsalaisissa kirkoissa huomattavasti runsaammin. ${ }^{75}$ Liuhan seinän käyttö on mahdollistanut rakennusten koon kasvamisen puhtaan lamasalvostekniikan avulla.

Suomalaisessa puurakentamisessa 1800-luvun puolivälistä alkaen tapahtunut muutos on ollut huomattavasti suurempi kuin on ymmärretty. Kyse ei ollut pelkästään siirtymisestä kattotuoleihin ja kivijalkoihin, jotka edellyttivät suoraa seinää, tiheää tapitusta ja muita tukirakenteita. Hirsirakennuksissa siirryttiin tuolloin rajoittamaan puun liikettä, mitä aiemmin oli pyritty hyödyntämään täysimääräisesti. 1950-luvulla oltiin jo niin pitkällä, että puun elämisestä eli painumisesta varoiteltiin jo kirjojen sivuilla. Elävästä ja kulttuurillemme ominaisimmasta materiaalista tuli ominaisuuksiltaan kielteistä, puun käyttö väheni ja sen sijaan tuotiin uusia teollisia materiaaleja.

Tämän rakennustavan kautta avautuu lukuisia mahdollisuuksia jatkotutkimukselle ja hirsirakentamisen uusille sovelluksille. Pohjanmaa on alavaa ja tuulista rannikkoaluetta. Se

\footnotetext{
${ }^{73}$ Ks. Mäkelä \& Riukulehto 2016, 6.

${ }^{74}$ Ks. Sjömar 2000, 129.

${ }^{75}$ Ks. Sjöström, Knapas \& Storsletten 2000, 249.
} 
on voinut vaikuttaa alueella yleistyneen asuinrakennuksen muotoon. Pohjanlahden itä- ja länsipuoli ovat maastollisesti erilaisia, mutta liuhaseinäisyyttä lukuun ottamatta talonpoikainen rakennuskanta on hyvin samankaltaista. Jatkotutkimuksen kannalta olisi mielenkiintoista tutkia, miten tuuli vaikuttaa liuhaan seinään ja talon ilmanvaihtoon, sillä paine-ero on riippuvainen paitsi tuulen suunnasta myös rakennuksen muodosta. ${ }^{76}$ Tähän tutkimuskysymykseen liittyvät myös erot liuhan ja pystysuoran seinän kosteuskäyttäytymisessä, esimerkiksi seinän kastumisessa ja kuivumisessa.

Lamasalvostekniikka perustuu puun ominaisuuksien ja liikkeen ymmärtämiseen. Todellisen ekologisen rakentamisen kehityksen kannalta olisi tutkittava puun ominaisuuksia ja rakenteita, joissa puun käyttäytymistä on hyödynnetty, ei vähiten rakenteiden yksinkertaisen toimivuuden ja tarkoituksenmukaisuuden vuoksi. Rakentamisen diversiteetin laajentaminen puhtaan puun käytön suuntaan luo mahdollisuuksia uusien sovellusten löytämiselle ja rakenteiden kehittymiselle.

$\overline{{ }^{76} \text { Lindberg 2009, 13-14. }}$

\title{
Lähteet ja kirjallisuus
}

\author{
Arkistolähteet \\ Kansallisarkisto (KA), Vaasa \\ Etelä-Pohjalaisen Osakunnan kotiseutuarkisto. \\ Matti Mäkelän kokoelmat (MMK), Lapua \\ Kenttätyöpäiväkirjat \\ Valokuvat \\ Pohjanmaan museo (PM), Vaasa \\ Pohjanmaan museon arkisto \\ Suomalaisen Kirjallisuuden Seura (SKS), Helsinki \\ Kansanrunousarkisto \\ Svenska Litteratur Sällskapet (SLS), Helsinki \\ Traditions- och språksamlingen
}




\section{Julkaistut lähteet}

Akustinen suunnittelu huoneen muodon perusteella. Saatavissa: http://fi.knaufdanoline.com/wp-content/ uploads/Room-shape_Fl.pdf Viitattu 30.4.2021.

Keskiaikaiset mitat. Saatavissa: http://www.katajala.net/keskiaika/elama/mitat.htm Viitattu 30.4.2021.

Marttilan remontti. Saatavissa: http://salmelankartano.fi/marttila-remontin-alla/ Viitattu 4.5.2021.

Suomen Sukuhistoriallinen yhdistys (SSHY)

Digitoidut kirkonkirjat

Lapuan kirkonarkisto. Rippikirjat.

https://www.sukuhistoria.fi/sshy/kirjat/Kirkonkirjat/lapua/lapua.htm Viitattu 30.4.2021

\section{Tutkimuskirjallisuus}

Andersson, Göran. 2016. Timmerbyggnader. Göteborg - Mariestad: Göteborgs universitet - Hantverkslaboratoriet.

Arnstberg, Karl-Olov. 1976. Datering av knuttimrade hus i Sverige. Stockholm: Nordiska museet.

Beskow, Hans. 1952. Bidrag till studiet av övre Norrlands kyrkor. Stockholm: Kungliga Vitterhets Historie och Antikvitets Akademie.

Bonns, Bertil. 1983. "Bondgårdens byggnadsskick." Teoksessa Svenska Österbottens historia IV. Vasa: Svenska Österbottens landskapsförbund.

Clarke, Edvard Daniel. (1819) 2000. Napapiirin takaa alas Pohjanmaalle 1799. Osa alkuteoksesta Travels in various countries of Europe, Asia and Africa. Turku: Idea Nova Oy.

Erixon, Sigurd. 1938. "Några bottniska byggnadsformer". Teoksessa Kulturhistoriska studier. Omistettu Nils Åbergille 24.7.1938. Stockholm: Generalstabens litografiska anstalts förlag.

Erixon, Sigurd. (1947) 1982. Svensk byggnadskultur. Stockholm: Institutet för folklivsforskning.

Ervi, Aarne. 1946. "Puurakennuksen suunnittelusta". Teoksessa Puurakennustaito. Helsinki: Oy Suomen Kirja.

Haikala, Antti. 2010. Suomalaisten tukipilarikirkkojen rakenteellinen toiminta ja korjaustavat. Diplomityö. Espoo: Aalto-yliopisto.

Hämäläinen, Albert. 1929. Seurasaaren ulkomuseo VI. Helsinki: Suomen kansallismuseo.

Itkonen, Erkki toim. 1992. Suomen sanojen alkuperä: Etymologinen sanakirja 1, A-K. Helsinki: SKS -Kotimaisten kielten tutkimuskeskus.

Jaakkola, Riitta. 2015. Rintakylissä ja larvamailla: Kurikan kulttuuriympäristöohjelma. Kurikka: Kurikan kaupunki.

Jokelainen, Janne. 2007. "Käsinveistotekniikan säännöistä hirsiarkkitehtuurille". Teoksessa Patinoituu ja paranee - Moderni puukaupunki -tutkijakoulu 2003-2006. Acta Universitatis Ouluensis C 264. Oulu: Teknillinen tiedekunta, Arkkitehtuurin osasto, Oulun yliopisto.

Klemetti, Heikki. 1927. Suomalaisia kirkonrakentajia 1600- ja 1700-luvuilla. Porvoo: WSOY.

Klemetti, Heikki. (1932) 1987. Kuortaneen vaiheita sanoin ja kuvin. Näköispainos pitäjän 300-vuotisjuhlajulkaisusta 1932. Porvoo: WSOY.

Koponen, Juha. 2011. Hirsitalojen rakenteiden liittymät ja niiden toimivuus. Aducate Reports and Books 9/2011. Joensuu: University of Eastern Finland.

Korhonen, Teppo. 2011. "The Heritage of Newcomers". Teoksessa CIAV VERNADOC 2010. Helsinki: Suomen ICOMOS.

Kulonen, Ulla-Maija. toim. 1995. Suomen sanojen alkuperä: Etymologinen sanakirja 2, L-P. Helsinki: SKS - Kotimaisten kielten tutkimuskeskus.

Kulonen, Ulla-Maija. toim. 2000. Suomen sanojen alkuperä: Etymologinen sanakirja 3,R-Ö. Helsinki: SKS Kotimaisten kielten tutkimuskeskus.

Lindberg, Fredrik. 2009. Täthet i timmerhus: Orsaker till luftläckage genom väggar av liggtimmer och hur det påverkar ventilation och energianvändning. Rakennustekniikan lopputyö. Gävle: Högskolan i Gävle. Saatavissa: http://www.diva-portal.org/smash/get/diva2:280876/FULLTEXT01.pdf Viitattu 30.4.2021.

Luukko, Armas. 1979. Vaasan historia 1721-1808. Il osa. Vaasa: Vaasan kaupunki.

Mäkelä, Matti ja Sulevi Riukulehto. 2016. Komeat pohjalaistalot. Seinäjoki - Mikkeli: Ruralia-instituutti.

Nikander, Gabriel. 1944. Gamlakarleby stads historia II. Gamlakarleby: Gamlakarleby stad.

Nilsson, Per Olov. 2013. Savutupa - paljon mainettaan parempi. Muutettu erikoispainos Metsähistorian seu- 
ran vuosikirjasta 2013. Täydellinen raportti Mattilan savutupa. Falun: Finnbygdens förlag.

Outhier, Reginald. (1744) 2011. Matka Pohjan perille 1736-1737. 2. tarkistettu ja täydennetty laitos. Ranskankielinen alkuteos Journal dún voyage au Nord. Tornio: Maupertuis-säätiö - Väylä-yhtiöt.

Pettersson, Lars. 1985. "Kyrkor och klockstaplar i svenska Österbotten". Teoksessa Svenska Österbottens historia V. Vasa: Svenska Österbottens landskapsförbund.

Pettersson, Lars. 1987. Templum Saloense. Pohjalaisen tukipilarikirkon arvoitus. Helsinki: Suomen muinaismuistoyhdistys ry.

Puurunen, Hannu. 1995. Hirsitalon rungon korjaus. Korjauskortisto 16. Helsinki: Museovirasto.

Roininen, R.H. (1957) 1971. Kirvestyöt. 3.painos. Helsinki: Rakentajain Kustannus Oy.

Sandoval, Bastian, Malin Skoglund ja Mats Nilsson. 2009. Rum i rum. Examensarbete. Karlstad: Karlstads universitet. Saatavissa: http://www.diva-portal.org/smash/get/diva2:222966/FULLTEXTo1.pdf Viitattu 30.4.2021.

Sappinen, Eero. 1985. Pohjois-Pohjanmaan maaseutupappiloiden rakennukset 1600-luvulla. Kansatieteellinen arkisto 34. Helsinki: Suomen muinaismuistoyhdistys ry.

Sirelius, U.T. 1921. Suomen kansanomaista kulttuuria II. Helsinki: Otava.

Sjömar, Peter. 1988. Byggnadsteknik och timmermanskonst: En studie med exempel från några medeltida kyrkor och allmogehus. Göteborg: Chalmers tekniska högskola.

Sjömar, Peter. 2000. "Byggnadsteknik och kyrkorum: Kyrklig timmerbyggnadskonst under 1600- och 1700-talen". Teoksessa Kyrka af träd. Helsinki - Oslo - Stockholm: Museiverket - NIKU - Riksantikvarieämbetet.

Sjöström, Ingrid, Marja-Terttu Knapas ja Ola Storsletten. 2000. Kyrka af träd: Kyrkobyggande under 1600och 1700-talen i Finland, Norge och Sverige. Helsingfors - Oslo - Stockholm: Museiverket - NIKU - Riksantikvarieämbetet.

Toivanen, Pekka. 1982. Bröderna Mommas skeppsvarv i Jakobstad 1666-1672. Jakobstads Museums publikationer nr 15. Jakobstads Museum.

Toivanen Pekka. 1983. "Suomalainen laivakauppa Tukholmaan vuosina 1765-1808". Teoksessa Scripta Historica VIII. Oulu: Oulun Historiaseura.

Valonen, Niilo. 1994. Suomen kansanrakennukset: Seurasaaren ulkomuseon rakennusten pohjalta. Helsinki: Seurasaarisäätiö.

Vilkuna, Kustaa. 1946. "Suomen kansanrakennusten historiaa". Teoksessa Puurakennustaito. Helsinki: Oy Suomen Kirja.

Vreim, Halvor. 1937. "Soliditetskravet i gammel bebyggelse". Teoksessa Byggekunst 1. Oslo: Norske arkitekters landsförbund.

Vuorela, Toivo. 1949. Etelä-Pohjanmaan kansanrakennukset. Kyrönmaa VI. Helsinki: Etelä-Pohjalainen osakunta. 


\section{LIITE 1. Artikkelin esimerkkikohteet.}

\section{Märijärvi}

Märijärven savutupa sijaitsee Kuortaneen museoalueella, jonne se on tuotu Kuortaneen Märijärveltä. Rakennus on yksihuoneinen ja sen ikkunaluukussa on vuosiluku 1700. Rakennuksen alimmat hirret pitenevät myös alaspäin muodostaen eräänlaisen jalustarakenteen.

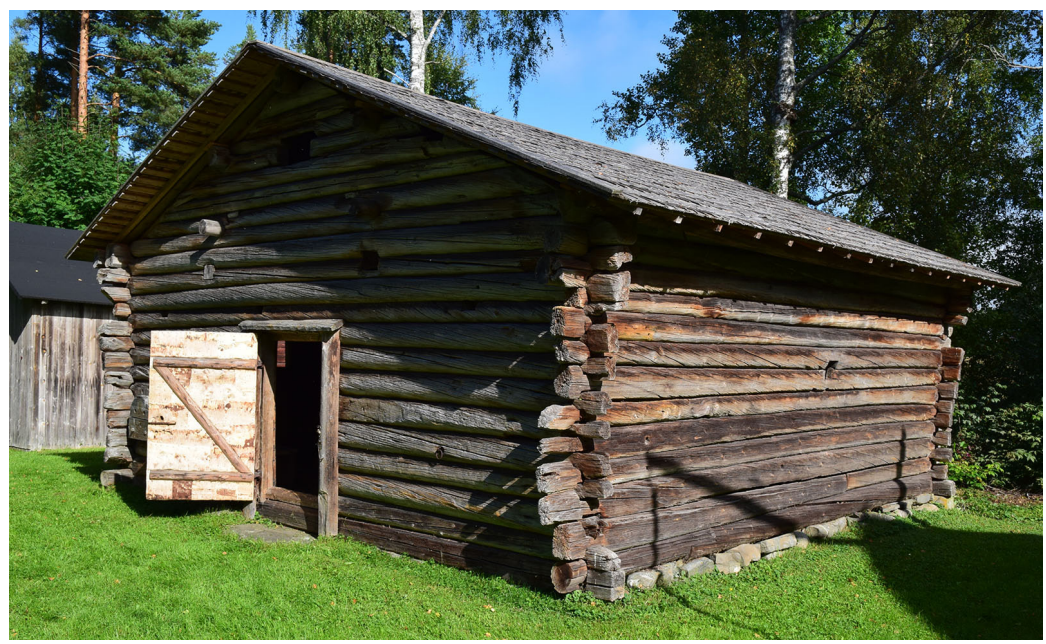

\section{Koivumäki}

Koivumäen torppa Lapuan Ruhassa on tuotu paikalleen 1700/1800 -lukujen vaihteessa. Talon toinen pää on siirretty, jonka jälkeen tilalle on tehty porstua ja kamari 1857. Tuvan pää levenee $5,47 \mathrm{~cm} /$ seinämetri.

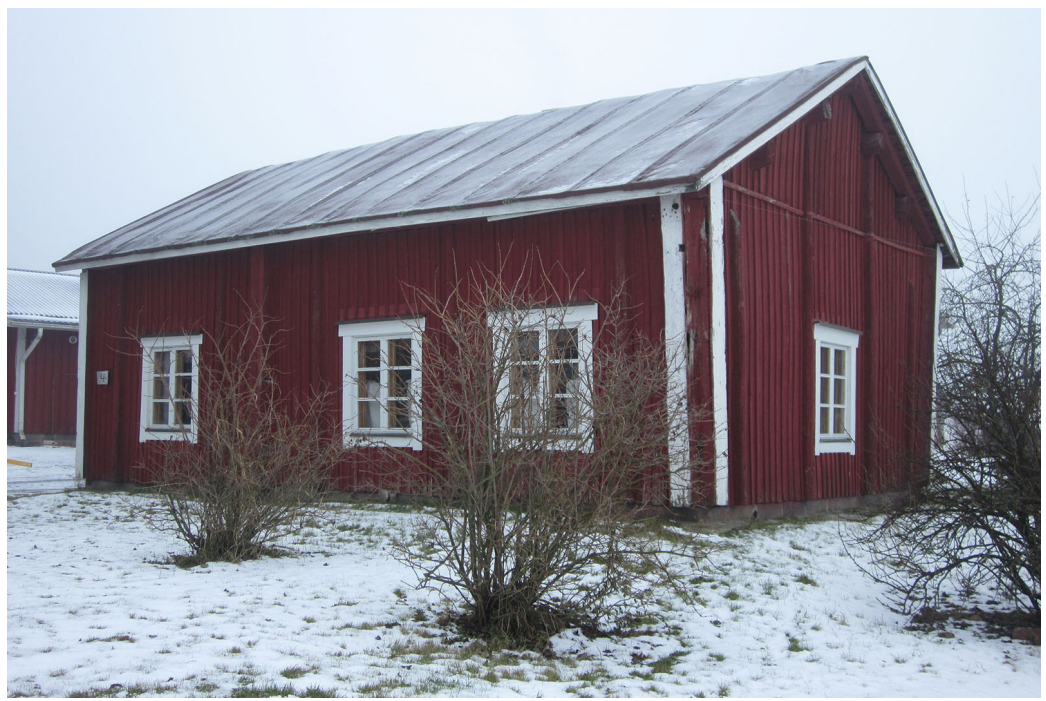




\section{Loukola}

Talo on ollut perimätiedon mukaan olemassa jo ison vihan aikana Kyrönjoen varrella, Ylistaron Topparlassa. Pohjanmaan museo siirsi rakennuksen Vanhaan Vaasaan, Falanderin talon pihapiiriin 1954. Siirrossa toinen tupa jätettiin pois. Porstuan pää levenee 2,25 cm / seinämetri.

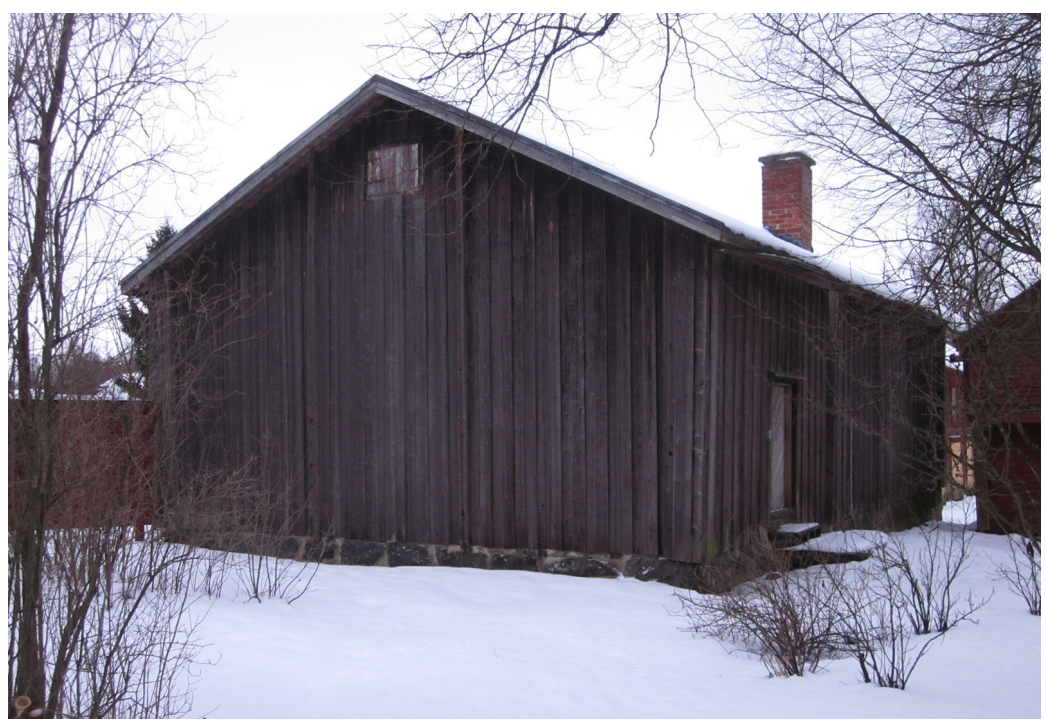

\section{Keski-Hynnilä}

Keski-Hynnilän talo toimii Kuortaneen museon pärakennuksena ja sen rakennusvuosi on 1774. Suuren tuvan ja porstuan sekä keskikamarin lisäksi talossa on erstupa, jonka sivulla on myös kamari. Rakennus tuotiin Kuortaneen museoalueelle 1958. Tuvan pää levenee 1,62 cm / seinämetri. Kuva Risto Känsälä.

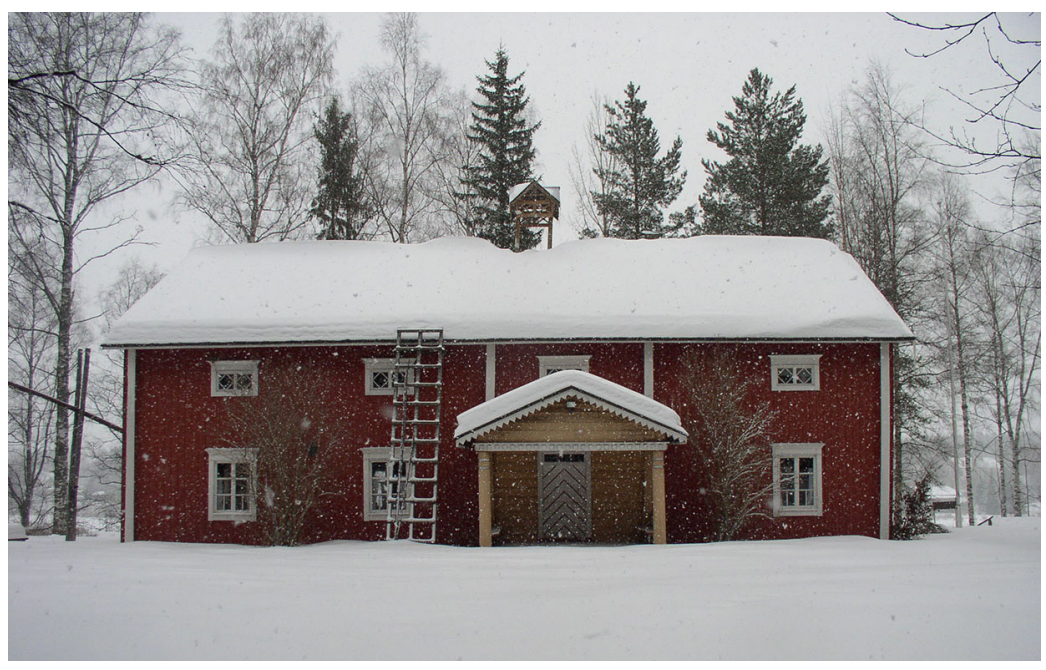




\section{Latva-Talvitie (alk. Kettula)}

Talon vanhin osa on rakennettu alun perin Jalasjärven Luopajärven rantaan Virnalanniemelle, mistä se on siirretty Kettulan tilan päärakennukseksi 1830 ja korotettu kaksikerroksiseksi 1831. Talo on jatkettu kamareilla ja ylätuvalla 1869. Rakennus siirrettiin Lapualle 2005. Tuvan pää levenee $2,39 \mathrm{~cm} /$ seinämetri. Kuvat tekijän, ellei toisin mainita.

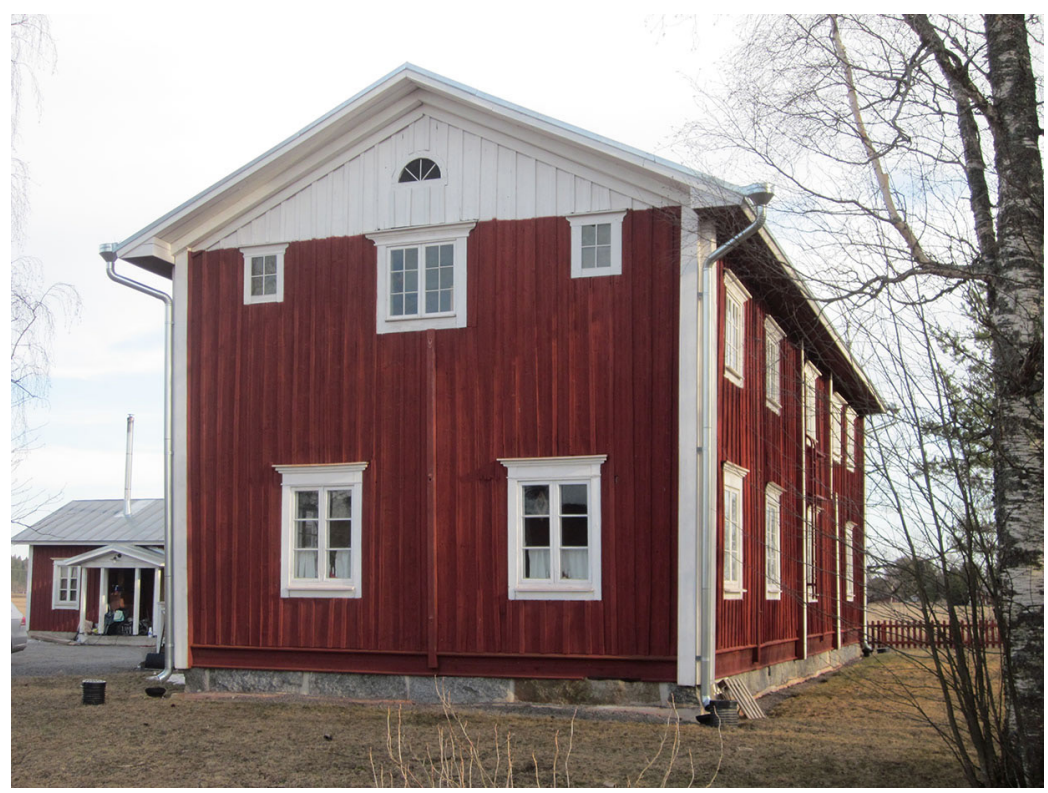

